\title{
Two Components of Aversive Memory in Drosophila, Anesthesia-Sensitive and Anesthesia-Resistant Memory, Require Distinct Domains Within the Rgk1 Small GTPase
}

\author{
Satoshi Murakami, ${ }^{1}$ Maki Minami-Ohtsubo, ${ }^{1}{ }^{\mathbb{C}}$ Ryuichiro Nakato, ${ }^{2}$ Katsuhiko Shirahige, ${ }^{2}$ and ${ }^{\oplus}$ Tetsuya Tabata ${ }^{1}$ \\ ${ }^{1}$ Laboratory of Neuroscience, Institute of Molecular and Cellular Biosciences, University of Tokyo, Tokyo 113-0032, Japan, and 2Laboratory of Genome \\ Structure and Function, Research Center for Epigenetic Disease, Institute of Molecular and Cellular Biosciences, University of Tokyo, Tokyo 113-0032, \\ Japan
}

Multiple components have been identified that exhibit different stabilities for aversive olfactory memory in Drosophila. These components have been defined by behavioral and genetic studies and genes specifically required for a specific component have also been identified. Intermediate-term memory generated after single cycle conditioning is divided into anesthesia-sensitive memory (ASM) and anesthesia-resistant memory (ARM), with the latter being more stable. We determined that the ASM and ARM pathways converged on the Rgk1 small GTPase and that the N-terminal domain-deleted Rgk1 was sufficient for ASM formation, whereas the full-length form was required for ARM formation. Rgk1 is specifically accumulated at the synaptic site of the Kenyon cells (KCs), the intrinsic neurons of the mushroom bodies, which play a pivotal role in olfactory memory formation. A higher than normal Rgk1 level enhanced memory retention, which is consistent with the result that Rgk1 suppressed Rac-dependent memory decay; these findings suggest that rgk1 bolsters ASM via the suppression of forgetting. We propose that Rgk1 plays a pivotal role in the regulation of memory stabilization by serving as a molecular node that resides at KC synapses, where the ASM and ARM pathway may interact.

Key words: Drosophila; forgetting; mushroom body; olfactory memory; RGK1; small G protein

Significance Statement

Memory consists of multiple components. Drosophila olfactory memory serves as a fundamental model with which to investigate the mechanisms that underlie memory formation and has provided genetic and molecular means to identify the components of memory, namely short-term, intermediate-term, and long-term memory, depending on how long the memory lasts. Intermediate memory is further divided into anesthesia-sensitive memory (ASM) and anesthesia-resistant memory (ARM), with the latter being more stable. We have identified a small GTPase in Drosophila, Rgk1, which plays a pivotal role in the regulation of olfactory memory stability. Rgk1 is required for both ASM and ARM. Moreover, N-terminal domain-deleted Rgk1 was sufficient for ASM formation, whereas the full-length form was required for ARM formation.

\section{Introduction}

Drosophila olfactory learning and memory, in which an odor is associated with stimuli that induce innate responses such as aver-

\footnotetext{
Received Nov. 27, 2016; revised March 12, 2017; accepted April 12, 2017

Author contributions:S.M. and T.T. designed research;S.M. and M.M.-0. performed research;S.M.,M.M.-0., R.N., and K.S. contributed unpublished reagents/analytic tools; S.M., R.N., K.S., and T.T. analyzed data; S.M. and T.T. wrote the paper.

This work was supported by grants-in-aid for Scientific Research from the Ministry of Education, Culture, Sports, Science and Technology (MEXT) of Japan (Grants 20115005 and 25115008 to T.T. and S.M.), Japan Society for the Promotion of Science (Grant 15K06700 to S.M.), the Takeda Science Foundation (T.T.), the Platform Project for Supporting in Drug Discovery and Life Science Research (Platform for Drug Discovery, Informatics, and Structural Life Science) from MEXT (K.S.), and the Japan Agency for Medical Research and Development (K.S.). We thank M. Saitoe, M. Heisenberg, H. Tanimoto, Y. Aso, A. Sugie, and T. Miyashita for providing fly strains and reagents; the Kyoto Drosophila Genetic Resource Center (DGRC), the National Institute of Genetics, the Bloomington Drosophila Stock Center (BDSC), the Berkeley Drosophila Genome Project, the Exelixis Collection, and the Developmental Studies
}

sion (Quinn et al., 1974; Tully and Quinn, 1985), has served as a useful model with which to elucidate the molecular basis of memory (Dudai, 1985; Davis, 1993, 1996; Waddell and Quinn, 2001; Heisenberg, 2003; Davis, 2005; Margulies et al., 2005; McGuire et al., 2005; Keene and Waddell, 2007). Olfactory memory is divided into several temporal components (Quinn and Dudai, 1976; Folkers et al., 1993; Tully et al., 1994; Heisenberg, 2003; Isabel

Hybridoma Bank for reagents; H. Tarui and K. Kurimoto for help with the RNA experiments; and members of Tabata laboratory for valuable comments and discussions.

The authors declare no competing financial interests.

Correspondence should be addressed to Tetsuya Tabata, Institute of Molecular and Cellular Biosciences, University of Tokyo, Yayoi 1-1-1, Tokyo 113-0032, Japan. E-mail: ttabata@iam.u-tokyo.ac.jp.

DOI:10.1523/JNEUROSCI.3648-16.2017

Copyright $\odot 2017$ the authors $\quad 0270-6474 / 17 / 375496-\bullet \$ 15.00 / 0$ 
et al., 2004; Trannoy et al., 2011; Plaçais et al., 2012; Bouzaiane et al., 2015) and the intermediate-term memory (ITM) generated after single cycle conditioning is further classified into two distinct phases, anesthesia-sensitive memory (ASM) and anesthesiaresistant memory (ARM) (Quinn and Dudai, 1976). Evidence has suggested that ASM and ARM are distinctly regulated at the neuronal level (Lee et al., 2011; Wu et al., 2013; Zhang et al., 2013; Bouzaiane et al., 2015) and at the molecular level (Dudai, 1988; Folkers et al., 1993; Schwaerzel et al., 2007; Knapek et al., 2010; Knapek et al., 2011; Scheunemann et al., 2012).

Mushroom bodies (MBs) represent the principal mediator of olfactory memory (Dubnau et al., 2003; Heisenberg, 2003; McGuire et al., 2005; Busto et al., 2010; Davis, 2011; GuvenOzkan and Davis, 2014; Hige et al., 2015a; Owald and Waddell, 2015; Barnstedt et al., 2016). Kenyon cells (KCs) are the intrinsic neurons of MBs, which are bilaterally located clusters of neurons that project anteriorly to form characteristic lobe structures and are a platform of MB-extrinsic neurons that project onto or out of the MBs (Tanaka et al., 2008; Aso et al., 2014). To elucidate the molecular mechanisms that underlie olfactory memory, screenings for MB-expressing genes have been a useful strategy (Han et al., 1992; Skoulakis et al., 1993). A technique used to examine gene expression in a small amount of tissue samples has enabled the investigation of the expression profile in MBs with a substantial dynamic range of expression levels and high sensitivity (Tang et al., 2009; Wang et al., 2009; Wang and Navin, 2015), thereby representing a promising approach with which to identify novel genes responsible for memory. We deep sequenced RNA isolated from adult MBs and identified $r g k 1$ as a KC-specific gene.

The RGK protein family, for which Drosophila Rgk1 exhibits significant protein homology, belongs to the Ras-related small GTPase subfamily, which is composed of Kir/Gem, Rad, Rem, and Rem2. Their roles include the regulation of $\mathrm{Ca}^{2+}$ channel activity (Béguin et al., 2001; Finlin et al., 2003) and the reorganization of cytoskeleton (Pan et al., 2000; Leone et al., 2001; Piddini et al., 2001; Ward et al., 2002). Notably, mammalian REM2 is expressed in the brain (Finlin et al., 2000) and has been shown to be important for synaptogenesis (Ghiretti and Paradis, 2011; Moore et al., 2013), as well as activity-dependent dendritic complexity (Ghiretti and Paradis, 2014; Ghiretti et al., 2014). These findings raise the possibility that RGK proteins may have a role in the synaptic plasticity that underlies memory formation. Drosophila has several genes that encode proteins homologous to the RGK family, including $r g k 1$ (Puhl et al., 2014). Therefore, based on the ample resources available in Drosophila for the investigation of neuronal morphology and functions (Keene and Waddell, 2007), Drosophila Rgk proteins will provide a good opportunity to elucidate the function of RGK family proteins.

Here, we describe the analysis of Drosophila rgk1, which exhibited specific expression in KCs. Rgk1 accumulated at synaptic sites and was required for olfactory aversive memory, making the current study the first to demonstrate the role of an RGK family protein in behavioral plasticity. Our data suggest that Rgk1 supports ASM via the suppression of Rac-dependent memory decay, whereas the N-terminal domain has a specific role in ARM formation. Together, these findings indicated that Rgk1 functions as a critical synaptic component that modulates the stability of olfactory memory.

\section{Materials and Methods}

Expression analysis of MBs with RNA-seq. Expression screening was designed to identify genes that are enriched in adult MBs. The RNA-seq analysis (subsequently described in detail) yielded a list of genes that were expressed in the MBs. We selected candidate genes for subsequent analysis with the following criteria: (1) genes highly expressed in the MBs, (2) genes that had not been reported previously to function in memory, and (3) genes that encode proteins that are homologous to mammalian proteins reported to regulate neuronal functions.

cDNA preparation for RNA-seq. Female flies that expressed green fluorescent protein (GFP) in KCs with OK107-Gal4 were maintained at $25^{\circ} \mathrm{C}$ before dissection. The flies were dissected under a fluorescent microscope in ice-cold PBS-BSA solution to isolate the MBs with tweezers. The isolated MBs were immediately lysed with $\mathrm{XB}$ buffer (PicoPure RNA isolation Kit; Thermo Fisher Scientific) at $42^{\circ} \mathrm{C}$ for $30 \mathrm{~min}$ and were subsequently maintained at $-80^{\circ} \mathrm{C}$ until RNA purification. After total RNA extraction and DNaseI treatment, the RNA quality was assessed with the Experion automated electrophoresis system (Bio-Rad). cDNA was generated from these RNA samples with a Superscript III kit (Invitrogen) and amplified following a previously described protocol $(\mathrm{Ku}-$ rimoto et al., 2007; Tang et al., 2009). The qualities of the final products were determined via qPCR with primers for gapdh, damb, and staufen.

RNA-seq analysis. cDNA samples were processed for RNA-seq analysis according to the manufacture's standard protocol (Applied Biosystems SOLiD Library Preparation protocol) and were sequenced on Applied Biosystems SOLiD platforms (SOLiD4 and 5500) to generate single-end 50 bp reads. Sequenced RNA reads were aligned to FlyBase mRNA database using Bowtie version 0.12.5 with the " $-\mathrm{v} 3-\mathrm{m} 10$ " option, which allows three mismatches in the first 28 bases and discards reads having $>10$ reportable alignments. Multiply aligned reads were divided equally among all locations ( $N$-times matched reads were weighted as $1 / N$ reads) and aligned transcript reads were merged for a single gene. The expression level of each gene was calculated in reads per kilobase per million reads. RNA-seq data have been deposited to Sequence Read Archive with the accession number SRP093518.

cDNA preparation for qPCR. Female flies were anesthetized with $\mathrm{CO}_{2}$ and, after decapitation, they were dissected in ice-cold PBS buffer that contained BSA to isolate the brains. After total RNA extraction, cDNA was synthesized with a Superscript III kit (Invitrogen).

$q P C R$ analysis. qPCR analysis was conducted with SYBR Green (Roche) on a Light Cycler 480 (Roche). For the quantification of rgkl isoforms in the brain, cDNAs of wild-type CS10 brains were used and qPCR assay was conducted with the following primers: $5^{\prime}$-TGATTA GCAGCGTCTCGACTG and 5'-TCTACAAGCGCATCTGCCG for the RA and RC isoforms and 5' -AGCAGCGTCTCGACTGTATTG and 5' ATCAACGTGACCGCGAATCC for the RB isoform.

FISH. DIG-labeled RNA probes were used for the FISH assay. The target sequence of the RNA probe spanned several rgkl exons (from 4175 to $4782 \mathrm{bp}$ in the $r g k 1$-RB isoform). A fragment of the $r g k 1$ gene was amplified with the primers $5^{\prime}$-TGTCTGCCCCAGCAGAGATCCA and 5'-TGCCTTCTGGGCGATGTTCTGA using ExTaq (Takara) from the adult female brain cDNA and cloned into a Topo cloning vector (Takara). After a sequence check, the in vitro translation was conducted using Sp6 or T7 RNA polymerase (Roche) and a DIG-labeling kit (Roche). The resultant probe was purified using QuickSpin columns for RNA (Roche). Fluorescent signals were generated using HNPP and FastRed (Roche). The signal recording was conducted using an LSM710 confocal microscope (Zeiss). The antibody for Dachshund (Developmental Studies Hybridoma Bank; DSHB) was used to label KC bodies.

Antiserum generation. A rabbit polyclonal antibody for Rgk1-PB was created by injecting rabbits with an HPLC-purified synthetic peptide, PGGTATTRSRGARA, which represented a portion of the N-terminal region that is only present in Rgk1-PB (74-87). Another rabbit polyclonal anti-Rgk1 (anti-Rgk1-C) was generated using two HPLC-purified peptides, GKELVARKRNSQQL (925-938) and PGSAQSSPRKYRGS (1334-1348), which correspond to a C-terminal region of the Rgk1 proteins. We confirmed that the sera recognized exogenously expressed Rgk1 in the adult brain.

Generation of transgenic flies (UAS-rgk1-RB). The entire length of the rgkl-RB was amplified using PrimeStar (Takara) from cDNA, which was synthesized from total RNA extracted from female CS10 brains. The following primers were used: $5^{\prime}$-CACAGATCTGCTTGGTCTGCATGA CTGCCGATCCCAT ATCGTTGTGC and 5'-CACTCTAGAGGATAA 
TCTCTGTGCTTAGAGTACATG CAGATTCTCG. The resultant fragment was cloned into the pUAST vector using the BglII and XbaI sites. Ligation was conducted with T4 ligase (Takara). The entire construct was verified by sequencing. Injections were applied onto a CS10 background by BestGene using standard P-element-mediated germline transformation.

Generation of transgenic flies (UAS-rgk1-RB fused with GFP). GFPfused UAS-Rgk1 constructs, full-length or truncated forms, were generated using the in-fusion technique (In-Fusion HD Cloning Kit; Clontech). The $\Delta \mathrm{C}$ construct lacks the sequence from tyrosine 1121 through the end of Rgk1-PB, which encompasses the entire GTPase domain. The $\Delta \mathrm{N}$ construct lacks the protein sequence from A.A.161 to 797, including the entire DUF2967 domain. Briefly, the pAcGFP fragment and each rgkl- $R B$ fragment (full, $\Delta \mathrm{N}$, or $\Delta \mathrm{C}$ ) were amplified using primers with linker sequences and linked using In-Fusion. GFPs were fused to the $\mathrm{N}$-terminal of the Rgk1 constructs. The pAcGFP1 vector (Clontech) and UAS-rgk1-RB (previously described) were used as templates for the amplifications. The resultant GFP-fused Rgk1 fragments were cloned using XhoI and XbaI sites into pJFRC7-20XUAS-IVS-mCD8::GFP (Addgene) after it was cut with $\mathrm{XhoI}$ and $\mathrm{XbaI}$ to remove $\mathrm{mCD} 8:$ GFP and provide room for the fragments. The entire construct was checked via sequencing. Injections were performed by BestGene in flies that possessed the attP site on the second chromosome (attP40).

Generation of transgenic flies (UAS-rgk1-S1134N). UAS-GFP-rgk1$\mathrm{S} 1134 \mathrm{~N}$ was generated using UAS-GFP-rgk1-RB as a template. A point mutation (AGT to AAT conversion) was introduced at serine 1134 to convert it to asparagine using In-Fusion with the following primer sets: 5' -CGGCCGCGGCTC GAGCAACATGACTGCCGATCCCATATCG and5'-GAGCGAATTCTTGCCCACCGCAGGACCT; 5' -GGCAAGAAT TCGCTCGTCTCGCAGTTCAT and 5'-ACAAA GATCCTCTAGATTA CTTGTACAGCTCATCCATGCCG. The entire constructs were checked via sequencing. Injections were performed by BestGene in flies with the attB site on the second chromosome (attP40).

Generation of the deletion allele. The $\mathrm{P}$ element was excised by crossing the KG00183 allele with the $\Delta 2-3$ strain, which has a P transposase (Robertson et al., 1988). The occurrences of imprecise excision and resultant deletions were determined via PCR with the following primers: $5^{\prime}$ ATGCGCCTCGCCTGTTTCTCGGGAAAATCTCCA and 5'-AAGCTA AGACCGA GGGAGCGTGACCCCAACCAC. The deletion of exons of the RA and RC isoforms was checked via PCR with the following primers: 5'-CGTTATATGTCCGTAAGGCACCGC and 5'-ATAGAGAGCCAT CCGAAAGCAAA GC. For rgk1-RB check: 5'-TCCTCAATGGTGAGC GTGTTG and 5'-CATCGCGC AAGAACTCCAAG. For gapdh check: 5'-ACGCCAAGGCTGGCATTTCG and 5'-AGGTCGATGACGCGGT TGGAG (see Fig. 2A). To determine the deleted gene region in the $\Delta r g k 1$ allele, a part of $r g k 1-R B$ was amplified from the female brain cDNA of $\Delta r g k l$ and sequence analysis indicated a frameshift in $r g k l-R B$ at $3405 \mathrm{bp}$, which causes a change in the resultant translated peptide, that is, QYV (765-767) to HPR followed by a stop codon. This change resulted in an open reading frame that encodes a truncated Rgk1 devoid of the entire homologous GTPase domain.

Generation of UAS-rgk1-sh. rgkl-short hairpin (rgk1-sh) was achieved following the online protocol available from the TRip website of Harvard Medical School (http://fgr.hms.harvard.edu/files/fly/files/2ndgenprotocol.pdf). The following target oligos were designed using an online design tool DSIR (http://biodev.extra.cea.fr/DSIR/DSIR.html) (Vert et al., 2006). The top strand was oligo 5'-CTAGCAGTGACCATGGATACACCGA AATGTAGTTATATTCAAGCATACA TTTCGGTGTATCCATGGTCG CG-3'; the bottom strand was oligo 5'-AATTCGCGA CCATGGATA CACCGAAATGTATGCTTGAATATAACTACATTTCGGTGTATCCA TGGTCACTG-3'. Oligos were synthesized (outsourced to operon) with NheI and EcoRI sites on each side and inserted into the VALIUM20 vector. After the sequence check, vectors were injected into the attP40 sites (BestGene). The insertion of the construct in the genome was checked by amplifying the construct from the extracted genome and sequencing it.

Immunohistochemistry. Adult female flies were anesthetized with $\mathrm{CO}_{2}$. Brains were dissected in ice-cold PBS solutions and fixed in $4 \%$ formaldehyde/PBS solutions for $20 \mathrm{~min}$ at room temperature, with the exception of the experiments that used anti-N-Rgk1-PB or anti-Rgk1-C, which required a shorter $(8 \mathrm{~min})$ room temperature fixation time to obtain signals. After 30 min of blocking with 5\% normal donkey serum (NDS; Jackson Laboratories) in PBS solution with $0.15 \%$ Triton X-100 (PBT), the brains were incubated at $4^{\circ} \mathrm{C}$ in a PBT solution that contained primary antibodies together with $1 \%$ NDS overnight. After the wash in PBT solution, the samples were incubated with a secondary antibody for $1 \mathrm{~d}$ at $4^{\circ} \mathrm{C}$. The antibody concentrations were as follows: anti-Rgk1-PB-N 1:200, anti-Rgk1-C 1:200, anti-Trio (9.4A; DSHB) 1:20, anti-Bruchpilot (Brp) (nc82; DSHB) 1:20, anti-Dlg (4F3; DSHB) 1:20, anti-Dachshund (mAbdac2-3; DSHB) 1:20, rat-anti-GFP (1A5, sc-101536; Santa Cruz Biotechnology) 1:50, goat anti-rat IgG-FITC (sc-2011) 1:200, rabbit-Cy3 1:200, and mouse-Cy3 1:200.

Imaging. Images were acquired with an LSM710 confocal microscope (Zeiss) using a $40 \times$ objective and were processed with ImageJ software. The images were adjusted for the brightness and contrast with Adobe Photoshop.

Fly stocks. Flies were maintained under a 12/12 h light-dark cycle on standard food at $25^{\circ} \mathrm{C}$ and $50-60 \%$ humidity. The strains used for the memory assays were outcrossed to CS10 at least six times with the exception of $d n c^{1}$, which was outcrossed to the Canton-S strain at least six times. When the white gene was not available as a marker to verify outcrossing, we checked the presence of mutations or transgenes via PCR or the Gal4 presence by crossing them with UAS-GFP and determining the GFP expression in each outcrossing cycle. The fly stocks included the following: c739-Gal4 (O'Dell et al., 1995), mb247-Gal4 (Zars et al., 2000), elav[c155]-Gal4 (Lin et al., 1994), rutabaga ${ }^{2080}$, dnc ${ }^{1}$. NP5225Gal4 (Hayashi et al., 2002), KG00183 (Bellen et al., 2004). CS10, hsflp; AYGal4 (Ito et al., 1997), tubGal80 ${ }^{\text {ts }}$ (McGuire et al., 2004). OK107-Gal4 (Connolly et al., 1996), Df(2R)BSC26 (Parks et al., 2004), and UAS$\mathrm{rac}^{\mathrm{V} 12}$ (Luo et al., 1994). The Gal4 lines 1993-Gal4 and 2765-Gal4 were originally generated and identified as MB-specific drivers in our laboratory (Abe et al., 2014).

Behavioral assays. Mixed populations of males and females were used for the assay unless otherwise noted. The CS10 strain was used as a control for the memory assay. Single sessions of olfactory aversive conditioning and the calculations of performance index were conducted according to previously described protocols (Tully and Quinn, 1985) using a semiautomated conditioning device (Murakami et al., 2010) with a modification that replaced odor cups with $25 \mathrm{ml} \times 2$ cups, which had been originally designed for $10 \mathrm{ml}$ odor. Memory tests were performed using a T-maze paradigm (Tully and Quinn, 1985). For all conditioning assays and tests, a 4-methylcyclohexanol (Fluka) dilution of 1:1000 in mineral oil and a 3-octanol (Fluka) dilution of 1:1000 in mineral oil were used. In a session of olfactory aversive conditioning, electric shock pulses of $1.5 \mathrm{~s}$ duration were applied 12 times with $5 \mathrm{~s}$ interpulse intervals. The conditioned flies were immediately tested or placed in empty vials to rest for 2 or $3 \mathrm{~h}$ before the memory test. To correct for a bias toward an odor, two groups of independent populations were reciprocally conditioned and tested to compensate for the innate preference to one of the odors.

Odor and shock avoidance. Olfactory acuity and shock reactivity were assayed in untrained flies using methods described previously (Berry et al., 2012). For odor avoidance, the avoidance index was calculated as the fraction of flies that avoided the odor minus the fraction of flies that did not. For shock avoidance, the avoidance index was calculated as the fraction of flies that avoided the electrified grid minus the fraction of flies that did not. The side with the odor or the side that is electrified was alternated to correct for side bias of the T maze.

Cold shock application. To anesthetize flies by cold shock, empty vials that contained flies were immersed in ice-cold water for $2 \mathrm{~min}$, followed by a rest at $25^{\circ} \mathrm{C}$ until the test. Cold shocks were applied $2 \mathrm{~h}$ after the conditioning and the flies were tested after resting for $1 \mathrm{~h}$ at $25^{\circ} \mathrm{C}$.

Statistical analysis. One-way ANOVA and Student's $t$ test analyses were performed with Kareidagraph (Synergy Software) and Excel (Microsoft). Post hoc tests were conducted with Fisher's least significant difference (LSD) tests after ANOVA to determine pairs of significance. The sample sizes are indicated on each bar in the graphs. All data are presented as the mean \pm SEM. 


$\mathrm{A}$
$\operatorname{rgk1-RC}$
$\operatorname{rgk1-RA}$
$\operatorname{rgk1-RB}$

B

Rgk1-PB

DUF2967

Putative GTPase domain

anti-Rgk1-RB-N anti-Rgk1-C anti-Rgk1-C

C

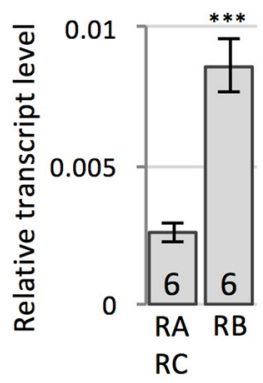

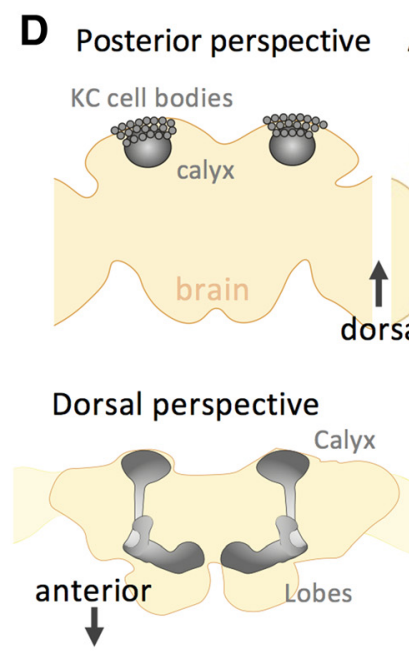

Anterior perspective
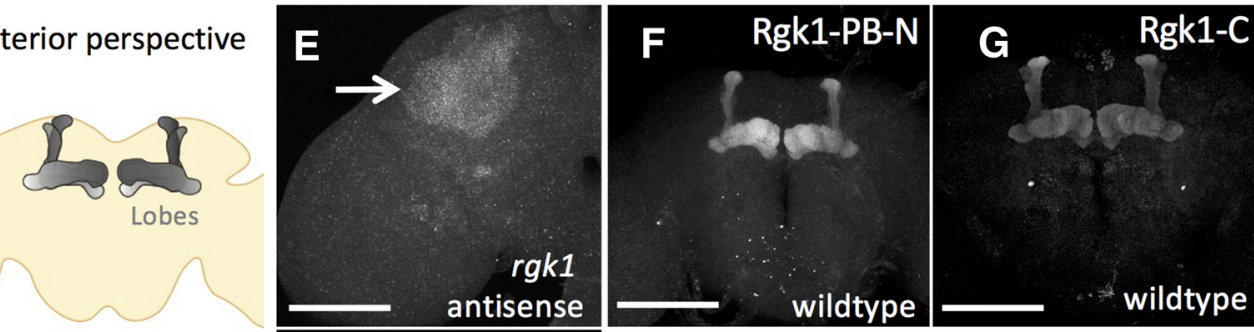

dorsal

\section{E}
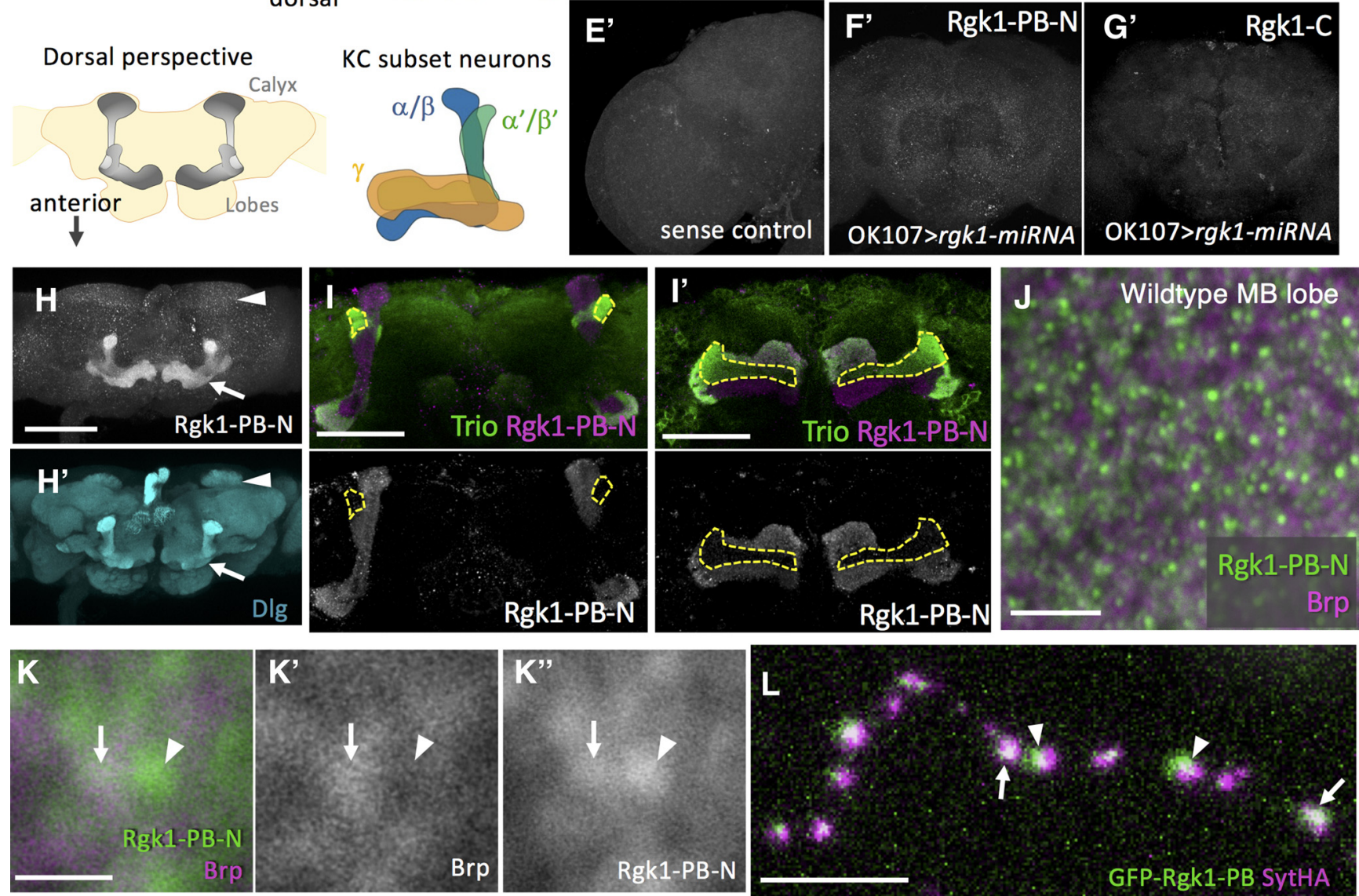

Figure 1. Exclusive expression of the $r g k 1$ gene and Rgk1 protein in the KCS. A, Schematic representation of the rgk1 gene locus. Red arrowheads indicate primer sites used to generate probes for RNA in situ hybridization assay. Green boxes represent first exons. $B$, Conserved domains of the Rgk1-PB protein encoded by the rgk1-RB isoform. Regions are indicated that are recognized by Rgk1 antibodies. C, Quantification of the amount of shorter isoforms ( $r g k 1-R A$ and $R C$ ) and the longer isoform (rgk1-RB) in the adult brain measured via qPCR ( $t$ test, $\left.{ }^{* * *} p=0.00069\right)$. Signals were normalized to the gapdh level. $\boldsymbol{D}$, Illustrations indicating the structure of $\mathrm{MBs}$ in the adult brain. KC bodies located at the posterior region of the brain extend dendrites locally to form the calyx (top left) and extend axons anteriorly to form lobe structures (top right and bottom left). The lobes are divided into three major cell types, $\alpha / \beta, \alpha^{\prime} / \beta^{\prime}$, and $\gamma$ (bottom right). E, Expression of the rgk1 transcript in the adult brain. The image indicates a brain hemisphere. Expression was strong and specific in the KCs (arrow). $\boldsymbol{E}^{\prime}, \mathrm{KC}$ signal was not detected with the rgk 1 sense probe. $\boldsymbol{F}, \mathbf{G}$, Polyclonal antibodies (anti-Rgk1-PB-N and anti-Rgk1-C) exclusively stained the MB lobes in the adult brain. $\boldsymbol{F}^{\prime}, \mathbf{G}^{\prime}, \mathrm{MB}$ signals were absent in animals that expressed rgk1-specific miRNA in the KCs. $\boldsymbol{H}_{,} \boldsymbol{H}^{\prime}$, Dorsal perspective of the adult brain stained with anti-Rgk1-PB-N $(\boldsymbol{H})$ and anti-Dlg $\left(\boldsymbol{H}^{\prime}\right)$. Signals were predominantly identified in the lobes (arrows) and were weak in the calyx and cell bodies (arrowheads) of the KCs. $I, I^{\prime}$, Different sections of a brain sample present $\alpha$ and $\alpha^{\prime}(I)$ and $\beta, \beta^{\prime}$, and $\gamma$ lobes $\left(I^{\prime}\right)$. The Rgk1-PB signal was weak in $\alpha^{\prime} / \beta^{\prime}$ neurons (circled by dotted lines) labeled with anti-Trio. J, Rgk1 protein (green) localization in the MB lobe ( $\gamma$ lobe). Rgk1 proteins formed puncta and exhibited a range of signal intensities. Anti-Brp was used to label synaptic active zones (magenta). $\boldsymbol{K}-\boldsymbol{K}^{\prime \prime}$, Magnified image of a part of $\boldsymbol{J}$. Rgk1 puncta were determined to be colocalized to the Brp signal (arrows) or resided next to the Brp signal (arrowheads). $\boldsymbol{L}$, Single-cell analysis of Rgk1 localization in a KC neuron. GFP-fused Rgk1 and HA-tagged synaptotagmin (SytHA) were induced in a single KC axon with hsflp and AYGal4. GFP-fused Rgk1 signal and SytHA signal colocalized (arrows) or resided next to each other (arrowheads). Scale bars: $\boldsymbol{E}-\boldsymbol{H}, 100 \mu \mathrm{m} ; \boldsymbol{I}, \boldsymbol{I}^{\prime}, 50 \mu \mathrm{m} ; \boldsymbol{J}, \boldsymbol{L}, 5 \mu \mathrm{m} ; \boldsymbol{K}, 1 \mu \mathrm{m}$. 
A

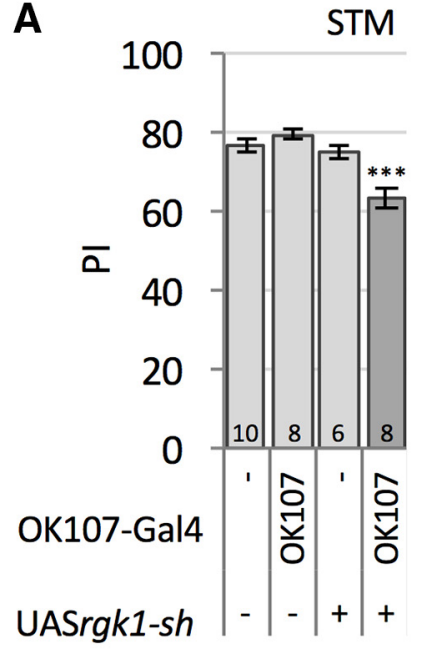

ITM B

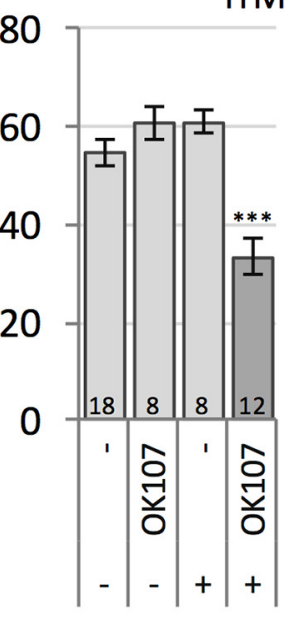

B

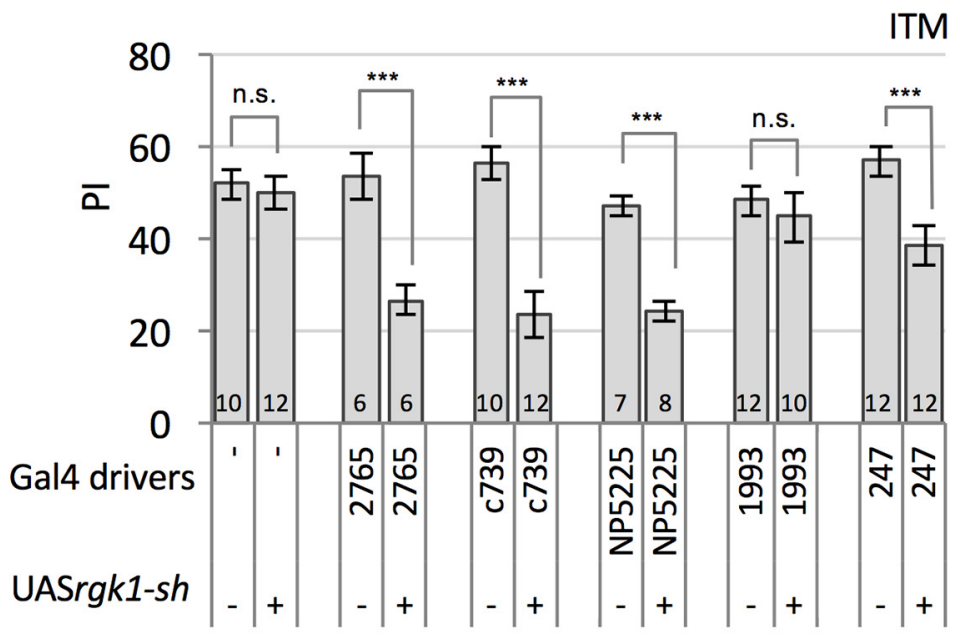

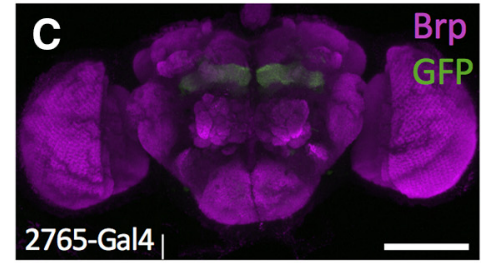
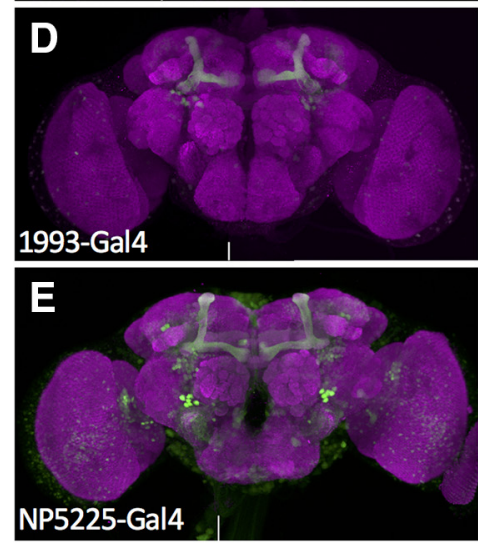

$\mathbf{F}$

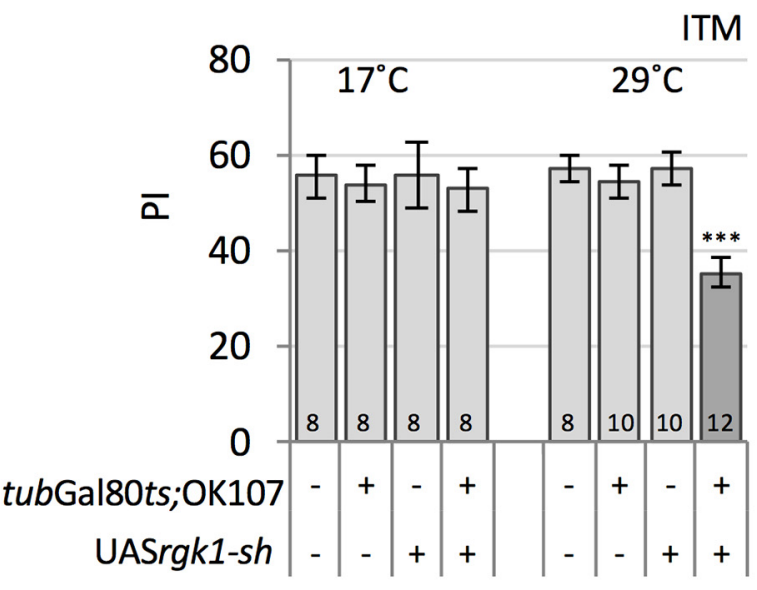

G

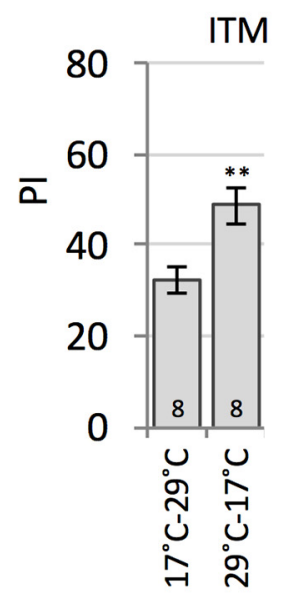

Figure 2. KC-specific knockdown of rgk1 with a specific miRNA resulted in a learning and memory defect. $A$, Expression of rgk1-specific miRNA (rgk1-sh) with OK107-Gal4 resulted in impairments of $2 \mathrm{~h}$ memory $\left(F_{(3,42)}=16.68, p<0.0001\right.$; Fisher's LSD test, 0 K107 $>$ rgk1-sh vs each of the controls $\left.* * * p<0.0001\right)$, as well as 5 min memory $\left(F_{(3,28)}=13.35, p<0.0001 ;\right.$ Fisher's LSD test, 0K107 $>$ rgk1-sh vs wild-type or Gal4-alone ${ }^{* * *} p<0.0001,0 K 107>$ rgk1-sh vs UAS-alone $\left.{ }^{* * *} p=0.0005\right)$. B. Cell-type-specific induction of miRNA in the KCs exhibited cell-type-specific reductions of memory $\left(F_{(11,105)}=9.31, p<0.0001\right.$; Fisher's LSD test, wild-type vs rgk1-sh-alone $p=0.818,2765>$ rgk1-sh vs 2765-alone ${ }^{* * *} p=0.0003$, c739 $>$ rgk1-sh vs c739-alone ${ }^{* * *} p<$ 0.0001, NP5225 $>$ rgk1-sh vs NP5225-alone ${ }^{* * *} p=0.0007,1993>$ rgk1-sh vs 1993-alone $p=0.504$, mb247 $>$ rgk1-sh vs mb247-alone $\left.{ }^{* * *} p=0.0004\right) .(C-E$, Expression patterns of 2765 -Gal4 (C), 1993-Gal4 (D), and NP5225-Gal4 (E) drivers. Images of left and right sides of the brain were obtained separately and subsequently combined to create entire brain images. Vertical white lines indicate where the images were combined. Scale bar, $100 \mu \mathrm{m}$. $\boldsymbol{F}$, rgk1-sh expression was conditionally induced using the TARGET system. Adult-stage-specific induction of rgk1-sh was sufficient to cause a $2 \mathrm{~h}$ memory defect $\left(17^{\circ} \mathrm{C}: F_{(3,28)}=0.082, p=0.969 ; 29^{\circ} \mathrm{C}: F_{(3,36)}=11.18, p<0.0001\right.$; Fisher's LSD test, tubGal80 ${ }^{\text {ts }} ; 0 \mathrm{~K} 107>$ rgk1-sh vs wild-type or UAS-rgk 1 -sh control ${ }^{* * *} p<0.0001$, tubGal $80^{\text {ts }} ; 0 \mathrm{~K} 107>\mathrm{rgk} 1$-sh vs tubGal80 ${ }^{\text {ts }} ; 0 \mathrm{~K} 107$ control ${ }^{* * *} \mathrm{p}=0.0001$ ). Adult flies were maintained at $17^{\circ} \mathrm{C}$ before they were shifted to $29^{\circ} \mathrm{C}$ for the $3 \mathrm{~d}$ induction. G, Cessation of rgk 1 -sh induction alleviated the memory defect ( $t$ test, ${ }^{* *} p=0.00385$ ). The genotype was UAS-rgk1-Sh;tubGal $80^{\text {ts }} ; 0 \mathrm{~K} 107.0$ ne population was kept at $17^{\circ} \mathrm{C}$ for $3 \mathrm{~d}$, followed by the incubation at $29^{\circ} \mathrm{C}$ for $3 \mathrm{~d}$. Another population was kept at $29^{\circ} \mathrm{C}$ for $3 \mathrm{~d}$, followed by the incubation at $17^{\circ} \mathrm{C}$ for $3 \mathrm{~d}$. The data are presented as the mean \pm SEM. $A, 5$ min and $2 \mathrm{~h}$ memory; $\boldsymbol{B}, \boldsymbol{F}, \mathbf{G}, 2 \mathrm{~h}$ memory. PI, Performance index; STM, short-term memory.

\section{Results}

Rgk1 was exclusively expressed in the adult KCs and accumulated at $\mathrm{KC}$ synaptic sites

We identified $r g k 1$ in a screening to identify genes that are highly expressed in the KCs of the MBs (refer to details in the Materials and Methods). Among the candidate genes, putative regulatory genes of neuronal functions were further examined for $\mathrm{KC}$ expression using an RNA in situ hybridization assay. Twenty-six genes were examined and eight genes exhibited a preferential expression in the adult KCs, including the mushroom-body expressed $(m u b)$ and retinal degeneration $C(r d g C)$ genes, which have been reported previously to be expressed preferentially in the MBs (Steele et al., 1992; Grams and Korge, 1998).

rgk1 encodes three isoforms, RA, RB, and RC (Fig. 1A), according to the flybase (http://flybase.org/reports/FBgn0264753. html). The RB isoform differs from the other two isoforms in that it encodes a protein that has an additional $\mathrm{N}$-terminal sequence, as well as a common region that contains the putative GTPase domain (Fig. 1B); RB was the most abundant isoform in the brain (Fig. 1C).

KCs are localized to the posterior side of the brain and extends axons anteriorly to form lobe structures (Fig. 1D). Among the 
Table 1. 0dor and shock avoidance for major genotypes and controls

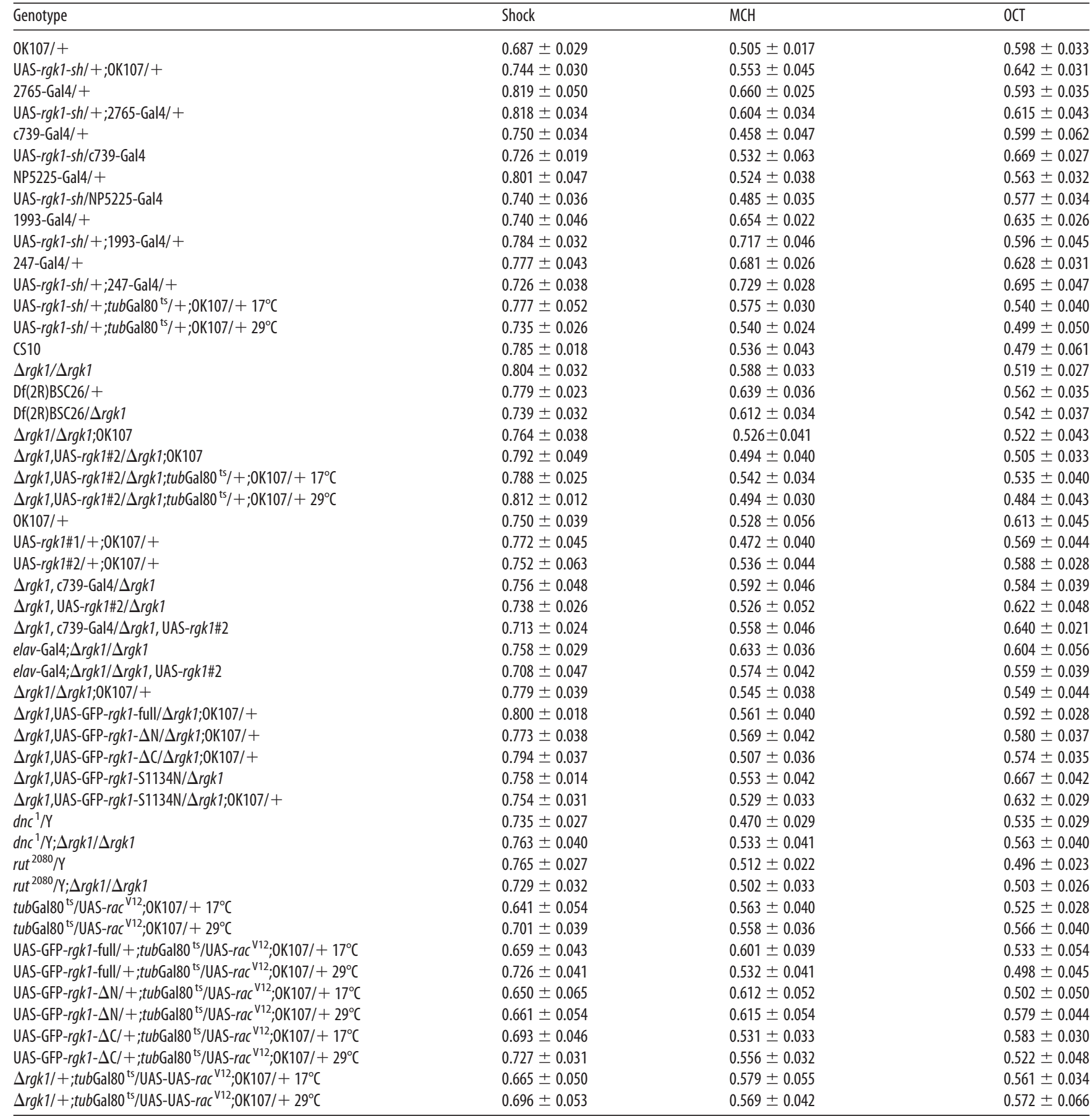

No significant differences were detected for any of the genotypes compared with the relevant controls (listed as pairs or groups) by Student's $t$ test or one-way ANOVA ( $n \geq 6$ per genotype). Avoidance of MCH and $0 C T$ were tested at $0.1 \%$ dilutions and electric shock at $60 \mathrm{~V}$. Data are presented as mean \pm SEM.

MCH, Methylcyclohexanol; OCT, 3-octanol.

identified genes in the screening, $r g k 1$ exhibited strong and nearly exclusive expression in the adult KCs (Fig. 1E).

To examine the expression of Rgk1 protein in the brain, polyclonal antibodies were raised against a region near the $\mathrm{N}$-terminal of Rgk1-PB or two sites in the C-terminal region of Rgk1 (Fig. $1 B)$. The anti-Rgk1-PB-N recognizes only Rgk1-PB. Both sera exclusively stained the MBs (Fig. $1 F, G$ ). These MB signals were virtually absent in the flies that expressed $r g k 1$-specific miRNA in the KCs (Fig. $1 F^{\prime}, G^{\prime}$ ), which suggests that the staining signals reflected Rgk1 protein expression. Rgk1 exhibited a polarized localization pattern in the KCs, including strong signals in the lobes and weaker signals in the calyx and $\mathrm{KC}$ bodies, as is evident when viewed from a dorsal perspective (Fig. $1 H, H^{\prime}$ ). Rgk1-PB exhibited a cell-type specificity in the KCs, which are classified into three major populations, including $\alpha / \beta, \alpha^{\prime} / \beta^{\prime}$, and $\gamma$ neurons; the expression was strong in the $\alpha / \beta$ and $\gamma$ neurons and weak in the $\alpha^{\prime} / \beta^{\prime}$ KCs (Fig. $1 I, I^{\prime}$ ). We also determined that the transgenic $r g k 1$ induction with pan-neural elav-Gal4 did not increase signals outside of the MBs, which suggests a regulatory mechanism that restricts Rgk1 to the KCs (data not shown). Overall, these findings indicate that Rgk1 is specifically expressed in KCs. 

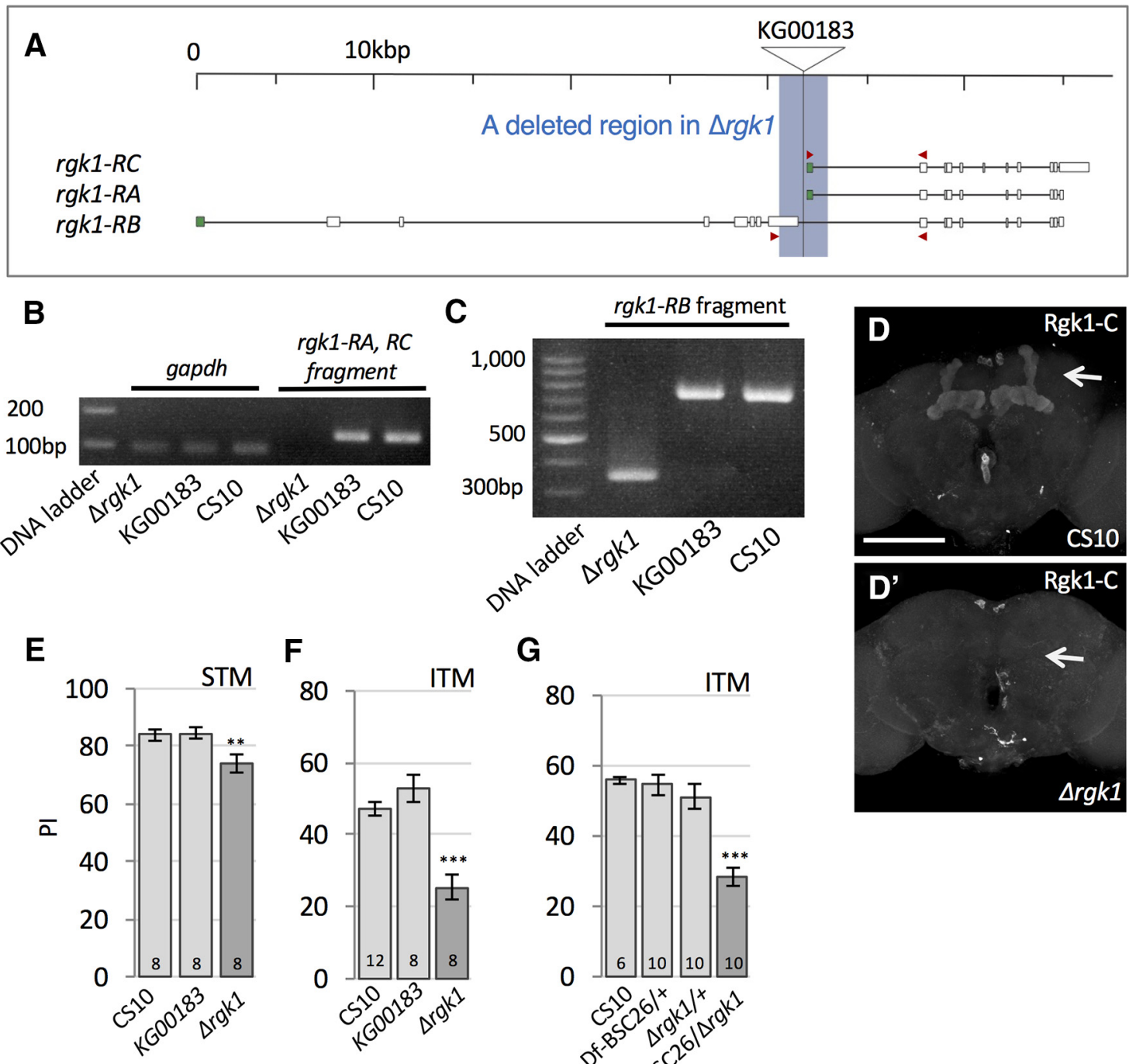

Figure 3. Genomic deletion mutant of $r g k 1$ exhibited learning and memory defects. $\boldsymbol{A}$, Schematic representation of the $r g k 1$ gene locus. Primer sites for $P C R$ analysis $(\boldsymbol{B}, \boldsymbol{C})$ are indicated (red arrowheads). Imprecise excision of the P-element from the KG00183 allele resulted in the deletion of a part of the rgk1 gene (indicated by the blue region). $\boldsymbol{B}, \boldsymbol{C}, \mathrm{PCR}$ analysis of the brain (DNAs indicated that the first exons of the RA and RC isoforms were absent in $\Delta r g k 1$ (B) and that a part of rgk1-RB mRNA was deleted in $\Delta r g k 1$ ( $)$. DNA ladder in B, 100 bp DNA ladder (Takara); DNA ladder in $\boldsymbol{C}, 1 \mathrm{~kb}$ mass ladder (Toyobo). $\boldsymbol{D}, \boldsymbol{D}^{\prime}$, Rgk1 signal in the MB was absent in the $\Delta$ rgk1 homozygous mutant (arrows). Scale bar, $100 \mu \mathrm{m}$. $\boldsymbol{E}$, , Homozygous mutant of $\Delta$ rgk 1 exhibited memory defects

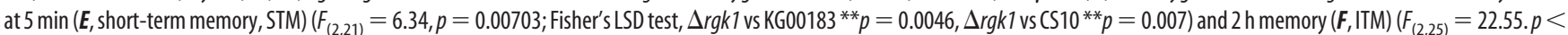
0.0001 ; Fisher's LSD test, $\Delta r g k 1$ vs CS10 or KG00183 ${ }^{* * *} p<0.0001$ ) after the olfactory aversive conditioning. $\mathbf{G}, \mathrm{A} 2 \mathrm{~h}$ memory impairment was identified in trans-hetero animals of $\Delta r g k 1$ and $\mathrm{Df}(2 \mathrm{R}) \mathrm{BSC} 26$, which lacks a genomic region including the entire rgk1 gene locus $\left(F_{(3,32)}=19.11 . p<0.0001\right.$; Fisher's LSD test, $\Delta \mathrm{rgk1/DfBSC26}$ vs each of the controls *** $\left.p<0.0001\right) . E$, 5 min memory; $\boldsymbol{F}, \mathbf{G}, 2 \mathrm{~h}$ memory. The data are presented as the mean \pm SEM. STM, Short-term memory.

We subsequently determined whether Rgk1 is present at KC output synapses, a site that is thought to be central in olfactory memory formation (Dubnau et al., 2001; McGuire et al., 2001; Schwaerzel et al., 2003; Barnstedt et al., 2016). We examined the distribution of Rgk 1 in the $\gamma$ lobes with the Rgk1 antibody, as well as anti-Brp, an active zone marker of synapses (Wagh et al., 2006). Rgk1 formed puncta that were intermingled with the Brp signal (Fig. $1 J$ ). Moreover, Rgk1 puncta were colocalized with the Brp signal or resided next to the signal (Fig. $\left.1 K-K^{\prime \prime}\right)$. However, MB lobes consist not only of intrinsic KCs but also extrinsic neurons, so it is difficult to determine whether Rgk1 puncta localize to KC synapses in these immunostaining experiments. We subsequently expressed GFP-fused Rgk1 stochastically and sparsely using $h s f l p$ and AYGal4 (Ito et al., 1997) in KCs, as well as a synaptic marker HA-tagged synaptotagmin (Robinson et al., 2002), to examine the Rgk1 localization in a single KC. We again identified two-tiered localization patterns: Rgk1 colocalized with syt-HA signals or next to syt-HA signals (Fig. $1 L$ ). We conclude that the localization of Rgk1 is closely associated with the presynapses of KCs.

\section{miRNA-mediated knockdown of rgkl in KCs caused memory defects}

To examine the role of the $r g k 1$ gene in olfactory learning and memory, we used an RNAi technique to knock down rgkl function in KCs, which is also useful to determine the neurons in which $r g k 1$ acts. An $r g k 1$-specific miRNA was generated according to the TRiP protocol (Ni et al., 2011) and was placed under the control of an upstream activating sequence (UAS) for target expression (Brand and Perrimon, 1993). We confirmed that the Rgk1 expression in the KCs was inhibited when UAS-rgk1-sh was crossed with OK107-Gal4, which is a KC-specific driver (Con- 

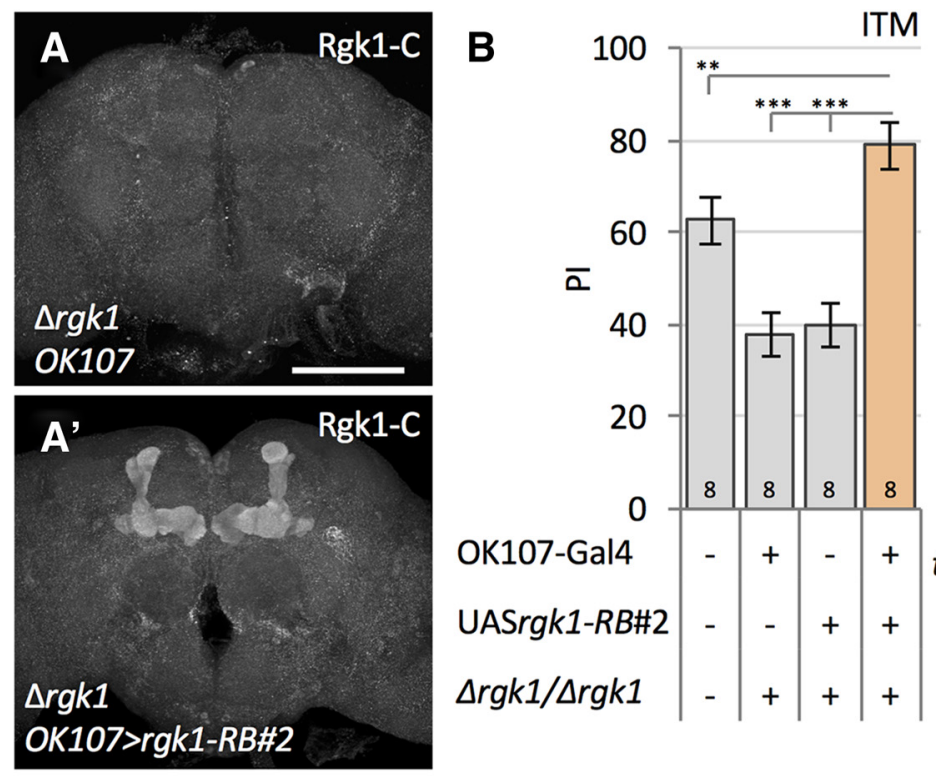

C

ITM

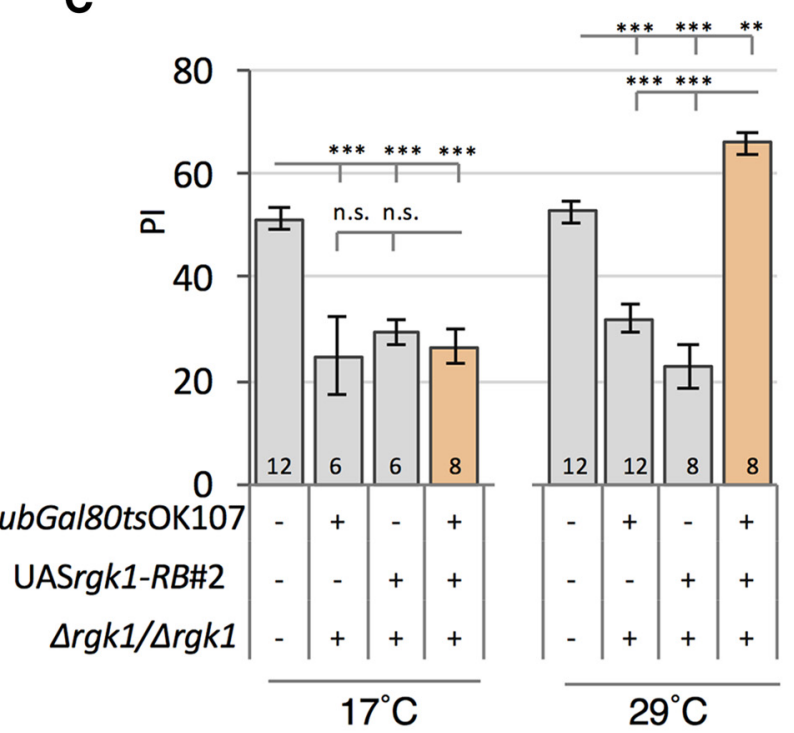

D

E
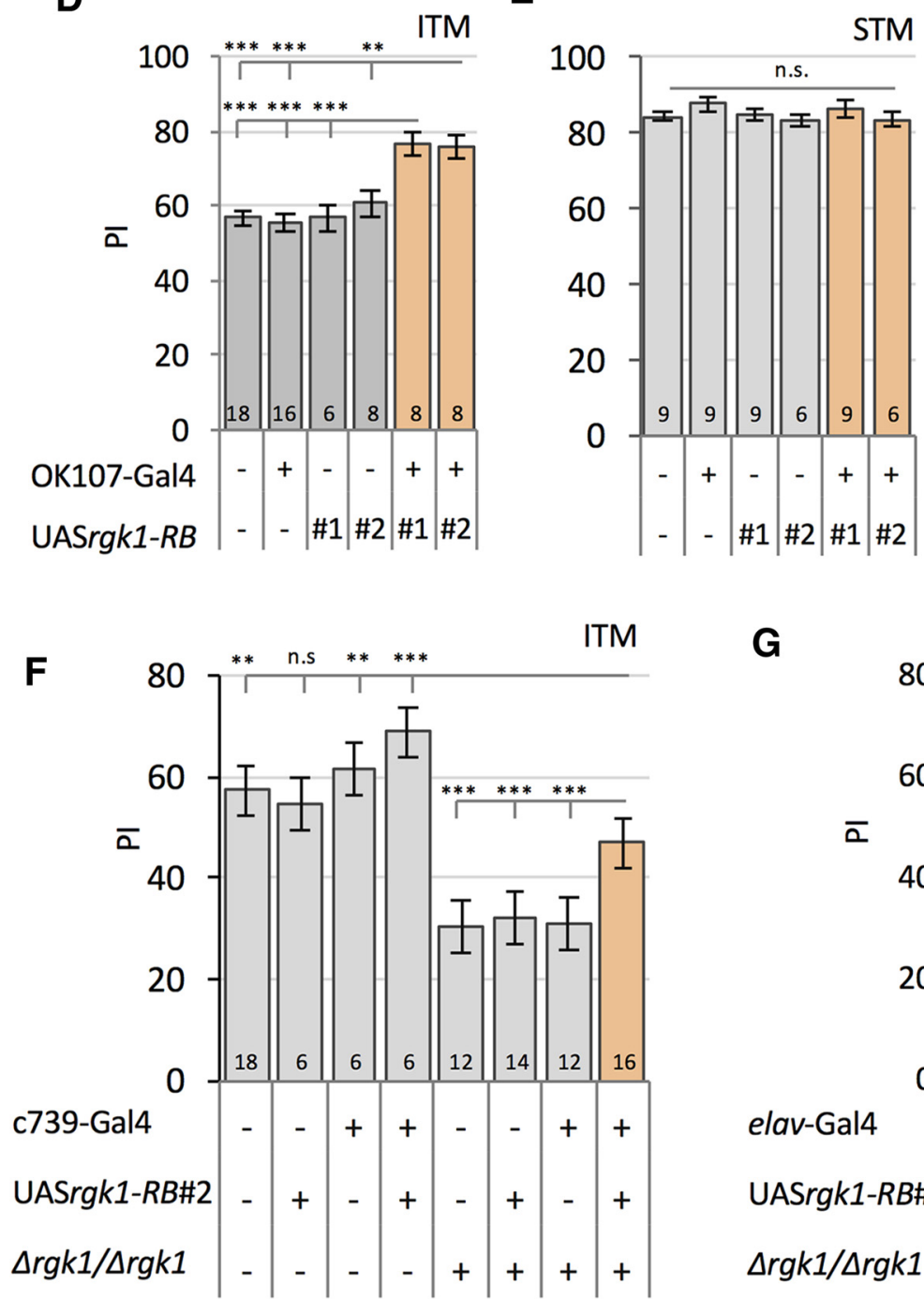

G

ITM

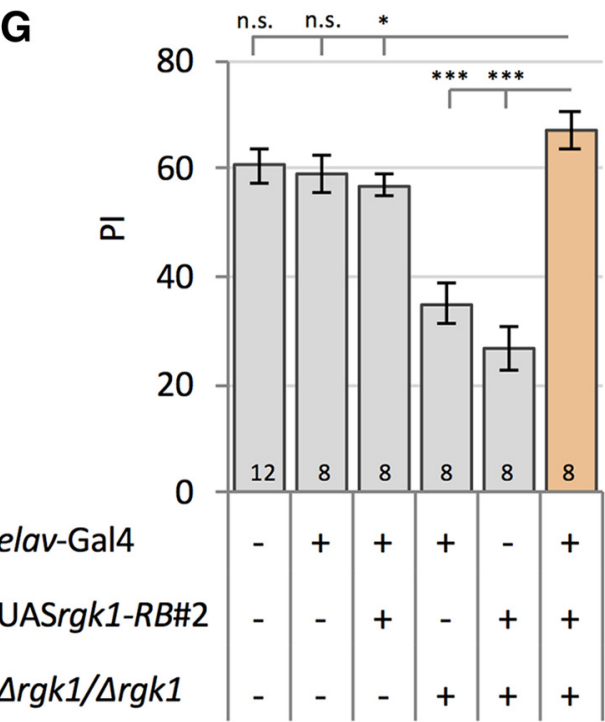

Figure 4. Rescue of the $\Delta r g k 1$ memory phenotype with $r g k 1-R B$ transgenes. $\boldsymbol{A}, \boldsymbol{A}^{\prime}$, Transgene induction with the 0K107-Gal4 driver restored Rgk1 expression in the KCs. Scale bar, $100 \mu \mathrm{m}$. $\boldsymbol{B}$, Memory defect of $\Delta r g k 1$ was rescued by transgene induction with 0 K107 $\left(F_{(3,28)}=24.72, p<0.0001\right.$; Fisher's LSD test, $\Delta r g k 1$ with 0K107/UAS-rgk1 vs $\Delta r g k 1$ with 0K107 or $\Delta r g k 1$ with UAS-rgk $\left.1^{* * *} p<0.0001\right)$. C, rgk1-RB transgene was conditionally induced at the adult stage with the TARGET system, which was sufficient for the rescue of the $\Delta r g k 1$ memory phenotype $\left(F_{(3,36)}=41.35\right.$, $p<0.0001$; Fisher's LSD test, $\Delta$ rgk1 with UAS-rgk1;tubGal80 ${ }^{\text {ts }} ; 0 \mathrm{~K} 10729^{\circ} \mathrm{C}$ vs $\Delta$ rgk1 with tubGal80 ${ }^{\text {ts. }}, 0 \mathrm{~K} 10729^{\circ} \mathrm{C}$ or $\Delta$ rgk1 with UAS-rgk1 $29^{\circ} \mathrm{C} * * * p<0.0001$ ). (Figure legend continues.) 
nolly et al., 1996; Fig. $\left.1 F^{\prime}, G^{\prime}\right)$. Memory performance was measured with an olfactory aversive conditioning assay (Tully and Quinn, 1985; Murakami et al., 2010). We determined that $2 \mathrm{~h}$ memory was severely affected in the rgkl-sh animals (Fig. 2A). Five-minute memory was also mildly affected in the $r g k 1-s h$ animals (Fig. 2A). The olfactory acuity and responses to electric shocks were intact in the rgkl-sh animals (Table 1), as well as the morphology of the MBs (data not shown). Therefore, these findings suggest that the KC-expressing $r g k 1$ gene was required for olfactory memory.

To further determine the subset of KCs that require $r g k 1$, UAS-rgk1-sh was crossed with MB-Gal4 drivers expressed in a subset of KCs (Fig. 2B-E). All Gal4s with the exception of 1993Gal4, which is specifically expressed in $\alpha^{\prime} / \beta^{\prime}$, exhibited impairments in memory performance (Fig. $2 B$ ), which suggests that rgkl is required in $\alpha / \beta$ and $\gamma$ neurons, but not in $\alpha^{\prime} / \beta^{\prime}$ neurons. This finding is consistent with the expression pattern of Rgk1-PB protein (Fig. $1 I, I^{\prime}$ ) in the adult MBs in which $\alpha^{\prime} / \beta^{\prime}$ neurons exhibited weaker Rgk1-PB expression. This expression pattern was also identified in the expression of NP5225-Gal4 (Hayashi et al., 2002; Fig. 2E), which has a gal4-reporter insertion 14 bp upstream of the transcription start site of the $r g k l$ gene.

To determine whether $r g k l$ is required for the development or physiological function of KCs, $r g k 1$-sh was conditionally induced only during the adult stage using the TARGET system (McGuire et al., 2004). A temporarily restricted induction of the hairpin in the adult KCs caused a memory defect (Fig. 2F), which suggests that $r g k 1$ is required at the adult stage, likely at the time when memory is formed. To gain further insights into the transient nature of $r g k 1$ function, $r g k$-sh induction was terminated after $3 \mathrm{~d}$ and memory performance was measured. The memory defect was alleviated after the cessation of the hairpin induction (Fig. $2 G$ ), which suggests that $r g k 1$ loss does not cause unrecoverable damage to neurons. Therefore, $r g k 1$ may act as a signaling molecule that regulates transient changes in neurons.

\section{Genomic disruption of $r g k 1$ causes memory defects}

To obtain an independent genetic confirmation that the rgk1 gene is required for olfactory memory, a genomic deletion allele was generated by imprecisely excising the P-element from the KG00183 allele that has a P insertion in the rgk1 gene locus (Bellen et al., 2004; Fig. 3A). The excision removed the first exons of the RA and RC isoforms (Fig. $3 B$ ) and partially deleted an exon of the RB isoform (Fig. 3C). The homozygote of the resultant $\Delta r g k 1$ allele was devoid of the Rgk1 signal in the MB, which was confirmed with a polyclonal antibody that targeted the C-terminal region of Rgk1 (Fig. 3D, $D^{\prime}$ ). The target region of the antibody is present in all $r g k 1$ isoforms, so this finding indicates that $\Delta r g k 1$ is

\section{$\leftarrow$}

(Figure legend continued.) Adult flies were maintained at $17^{\circ} \mathrm{C}$ before they were shifted to $29^{\circ} \mathrm{C}$ for the 3 dinduction. $D$, When expressed with 0K107-Gal4, rgk1 transgene enhanced $2 \mathrm{~h}$ memory in the wild-type $\left(F_{(5,58)}=11.26, p<0.0001\right.$; Fisher's LSD test, 0K107>UAS-rgk1\#1 vs wild-type or 0K107 control ${ }^{* * *} p<0.0001,0 K 107>$ UAS-rgk1\#1 vs UAS-rgk1\#1 control ${ }^{* * *} p=0.0002$, 0K107>UAS-rgk1\#2 vs wild-type or 0K107 control ${ }^{* * *} p<0.0001$, 0K107> UAS-rgk1\#2 vs UAS-rgk1\#2 control $\left.{ }^{* *} p=0.0013\right)$. $E$, Enhancement was not identified in short-term memory $\left(F_{(5,42)}=0.8096, p=0.549\right)$. $\boldsymbol{F}$, Rescue of memory phenotype was also observed with $\alpha / \beta$-specific c739-Gal4 $\left(F_{(7,82)}=25.44, p<0.0001\right.$; Fisher's LSD test, $\Delta r g k 1$ with c739/UAS-rgk1 vs $\Delta r g k 1$ with c739 or $\Delta r g k 1$ with UAS-rgk1 or $\Delta r g k 1$-alone $\left.{ }^{* * *} p<0.0001\right)$. G, Full rescue of the $\Delta r g k 1$ memory defect was identified with pan-neuronal elav-Gal4 $\left(F_{(5.46)}=21.79, p<0.0001\right.$; Fisher's LSD test, $\Delta r g k 1$ with elavGal4;UAS-rgk1 vs $\Delta r g k 1$ with elavGal4 or elavGal4;UAS-rgk $\left.1^{* * *} p<0.0001\right) . \boldsymbol{B}-\boldsymbol{D}, 2 \mathrm{~h}$ memory. $\boldsymbol{E}, 5 \mathrm{~min}$ memory. $\boldsymbol{F}, \boldsymbol{G}, 2 \mathrm{~h}$ memory. The data are presented as the mean \pm SEM. STM, Short-term memory. devoid of products of all $r g k 1$ isoforms. The morphology of the MBs was intact in the deletion allele. The $\Delta r g k 1$ homozygous mutants were viable, which enabled us to measure their memory performance at the adult stage. The original line KG00183 did not exhibit memory defects, whereas the $\Delta r g k 1$ homozygous mutants exhibited an impairment in $2 \mathrm{~h}$ memory, as well as slight decreases in the scores 5 min after the olfactory aversive training (Fig. $3 E, F)$, thereby reproducing the results of the miRNAmediated knockdown experiment. The memory defect of $\Delta r g k 1$ was not complemented by the deletion allele Df(2R)BSC26, which lacks the entire $r g k 1$ gene (Fig. $3 G$ ). The olfactory acuity and responsiveness to electric shock were indistinguishable between the wild-type and $\Delta r g k 1$ (Table 1). Therefore, these findings indicate that the $r g k 1$ gene is necessary for olfactory memory.

\section{$\Delta r g k 1$ memory phenotype was rescued by rgk1 transgene induction in KCs}

To further confirm the role of KC-expressing rgk1 in olfactory memory, UAS-rgk1-RB was generated to determine whether exogenous expression of the rgkl transgene in KCs rescues the $\Delta r g k 1$ memory phenotype. We confirmed that the expression of Rgk1 was restored in the KCs in flies that possessed the UASrgk1-RB and KC-Gal4 drivers (Fig. $4 A$ and data not shown). The memory performance was rescued by transgene induction with OK107-Gal4 (Fig. 4B) or by conditionally expressing the $r g k 1-R B$ transgene at the adult stage with the TARGET system that used OK107-Gal4 (Fig. 4C). Therefore, $r g k 1$ is required in KCs for olfactory memory at the adult stage, which is compatible with the results of the adult-specific induction of $r g k 1$-miRNA (Fig. 2E).

We identified a memory enhancement in rescued flies (Fig. $4 B, C)$. The $2 \mathrm{~h}$ memory score was significantly increased in flies that expressed transgenic $r g k 1$ in the $\operatorname{MBs}\left(F_{(3,28)}=24.72, p<\right.$ 0.0001 . Fisher's LSD test, rescued flies vs wild-type flies ${ }^{* *} p=$ 0.0074 , Fig. $4 B ; F_{(3,32)}=37.56, p<0.0001$; Fisher's LSD test, rescued flies vs wild-type flies $29^{\circ} \mathrm{C}^{\star *} p=0.0058$; Fig. $4 C$ ). Therefore, we aimed to determine whether $r g k 1$ overexpression could enhance memory in the wild-type flies. When $r g k 1-R B$ was overexpressed in the KCs of wild-type, $2 \mathrm{~h}$ memory was enhanced (Fig. 4D). The enhancement was observed with two independent UAS- $r g k 1-R B$ lines, but was not observed in short-term memory (Fig. 4E), which suggests that $r g k 1$ has a critical role in ITM and potentially in memory retention.

The rescue of the memory performance was also observed with c739-Gal4 or the pan-neuronal elav-Gal4 driver (Fig. 4F, G), but the enhancement was not obvious with these Gal4 lines. This might be due to the difference in the strength and/or the cell-type specificity of the Gal4 expression. Experiments with more Gal4 drivers will be required to test this possibility.

\section{C- and N-terminal regions of Rgk1 have distinct roles in memory}

$r g k 1-R B$ encodes a putative GTPase domain that exhibits homology to mammalian Ras and RGK proteins, as well as a domain specific to Drosophila (DUF2967), the function of which is unknown (Fig. 5A). Considering the conserved nature of the GTPase domain, it is of particular interest whether the putative GTPase domain is indispensable for the function of $r g k l$ in memory. Therefore, to gain insights regarding the function of these domains, partially deleted $r g k l$ constructs were generated (Fig. $5 A)$. GFP was attached to the N-terminus of the constructs. To minimize the possible negative effect of tagging the protein with GFP (Hanson and Ziegler, 2004), we avoided the C-terminal of Rgk1 as the GFP-fusion site because the C-terminal motif is highly 
A

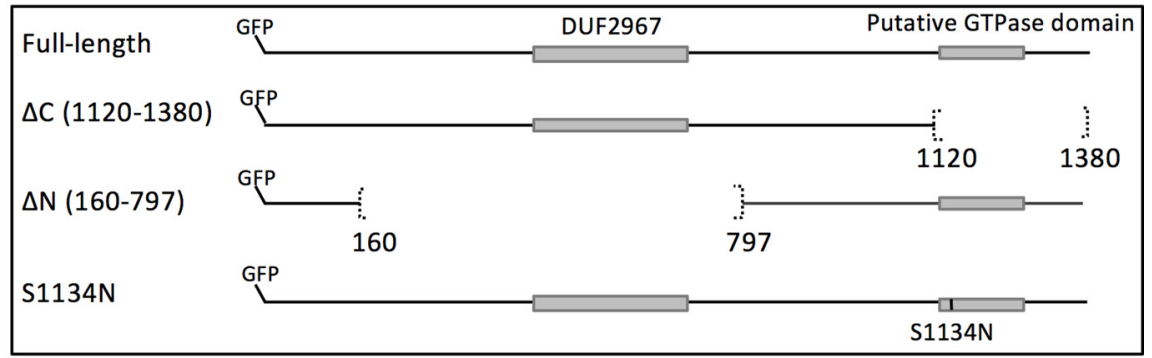

B

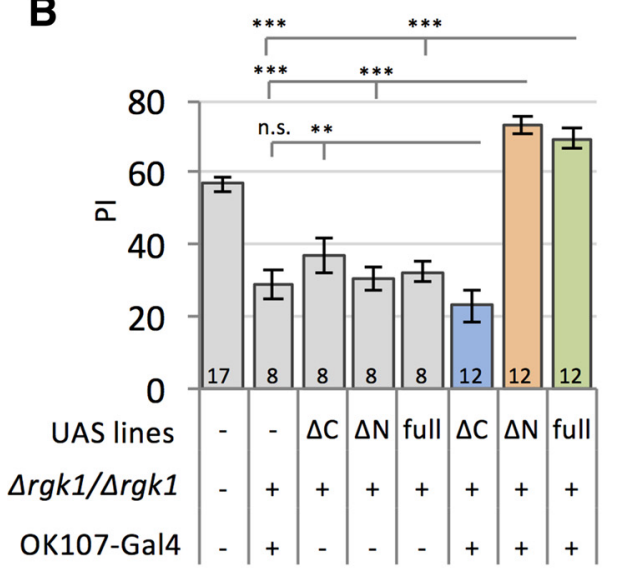

C

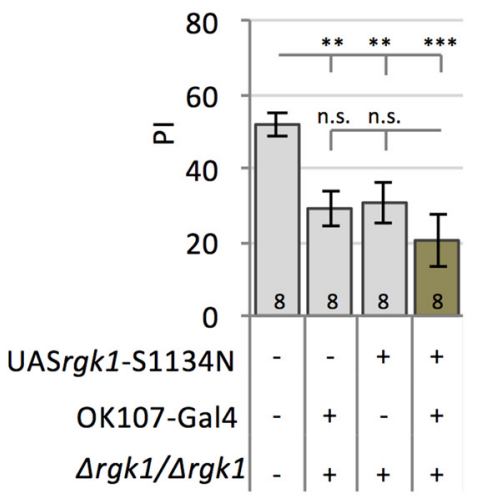

D

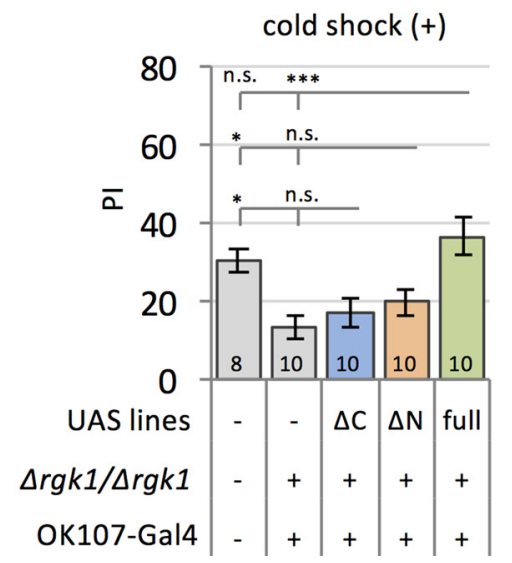

Figure 5. Requirement of Rgk1 protein regions in memory. $A$, Schematic representations of GFP-fused transgenes that encode full-length and truncated forms of Rgk1 or Rgk1 with an amino acid substitution in the putative GTPase domain. Digits denote the position in the protein sequence. $\boldsymbol{B}$, Transgene that lacked the C-terminal region $(\Delta C)$ failed to rescue the $\Delta r g k 1$ memory phenotype, whereas the full-length and $\Delta N$ constructs exhibited full rescues $\left(F_{(7,77)}=37.13, p<0.0001\right.$; Fisher's LSD test, $\Delta$ rgk1 with UASrgk1-full;0K107 vs $\Delta r g k 1$ with UASrgk1-full or $\Delta r g k 1$ with $0 K 107{ }^{* * *} p<0.0001, \Delta r g k 1$ with UASrgk1 $\Delta$ N;0K107 vs $\Delta r g k 1$ with UASrgk1 $\mathrm{N}$ or $\Delta r g k 1$ with 0 K107 ${ }^{* * *} p<0.0001, \Delta r g k 1$ with UASrgk1 $\Delta C ; 0 K 107$ vs $\Delta r g k 1$ with UASrgk1 $\Delta C^{* *} p=$ $0.0049, \Delta r g k 1$ with UAS-rgk1 $\Delta$ C;0K107 vs $\Delta r g k 1$ with 0K107 $p=0.209)$. C, Transgene that had a single amino acid substitution in the putative GTPase domain (S1134 to $\mathrm{N})$ failed to rescue the $\Delta r g k 1$ memory phenotype $\left(F_{(3,28)}=6.39 . p=0.00194\right.$; Fisher's LSD test, $\Delta r g k 1$ with UASrgk1-S1134N;0K107 vs $\Delta r g k 1$ with UASrgk1-S1134N $p=0.199, \Delta r g k 1$ with UASrgk1-S1134N;0K107 vs $\Delta r g k 1$ with 0 K107 $p=0.258)$. D, Rescue experiments with the application of cold shock anesthesia. After the cold shock, only the full-length transgene rescued the $\Delta r g k 1$ phenotype, in contrast to $\operatorname{Rgk} 1 \Delta \mathrm{N}$ and $\operatorname{Rgk} 1 \Delta \mathrm{C}\left(F_{(4,43)}=6.72 . p=0.00027\right.$; Fisher's LSD test, $\Delta r g k 1$ with UASrgk1-full;0K107 vs $\Delta r g k 1$ with 0 K107 ${ }^{* * *} p<0.0001, \Delta r g k 1$ with UASrgk1-full;0K107 vs wild-type $p=0.274, \Delta r g k 1$ with UASrgk1 $\Delta \mathrm{N} ; 0 \mathrm{~K} 107$ vs $\Delta r g k 1$ with $0 K 107 p=0.315, \Delta r g k 1$ with UASrgk1 $\Delta \mathrm{N} ; 0 \mathrm{~K} 107$ vs wild-type $* p=$ $0.0443, \Delta r g k 1$ with UASrgk1 $\Delta$ C;0K107 vs $\Delta r g k 1$ with 0K107 $p=0.505, \Delta r g k 1$ with UASrgk1 $\Delta C ; 0 K 107$ vs wild-type ${ }^{*} p=$ 0.021). $\boldsymbol{B}-\boldsymbol{D}, 3 \mathrm{~h}$ memory. The data are presented as the mean \pm SEM. synaptic sites (data not shown). The constructs were tested using an olfactory aversive memory assay for their ability to rescue the $\Delta$ rgkl memory phenotype. The results presented so far indicated that Rgk1 is important for the modulation of the ITM. We sought to focus the subsequent analysis on ITM, especially on the roles of Rgk1 in ASM and ARM. Because previous studies typically measured ITM $3 \mathrm{~h}$ after the training (Shuai et al., 2010; Knapek et al., 2011; Bouzaiane et al., 2015; Cervantes-Sandoval et al., 2016), we decided to use $3 \mathrm{~h}$ memory in the subsequent ITM examinations. The full-length and $\Delta \mathrm{N}$ constructs $(\Delta 160-797)$ rescued the $3 \mathrm{~h}$ memory defect, in contrast to the $\Delta \mathrm{C}$ construct $(\Delta 1120-1380$ in Rgk1-PB; Fig. $5 B)$; these findings indicate that the C-terminal region, which includes a putative GTPase domain, is critical for memory. The substitution of serine 17 for asparagine in $\mathrm{Ras}^{\mathrm{N} 17}$ inhibits the activation of Ras (Farnsworth and Feig, 1991) and has been used as a dominant-negative form of Ras (Feig and Cooper, 1988). The sequence near Serine 17 of Ras is highly conserved in Drosophila Rgk1. To determine whether the homologous GTPase domain in Rgk1 is important for memory, we generated a transgene that mimicked $\mathrm{Ras}^{\mathrm{N} 17}$, which has a single amino acid substitution (S1134 to N) at the corresponding position to that of $\mathrm{Ras}^{\mathrm{N} 17}$. We determined that UAS-rgk1-S1134N was not able to rescue the $\Delta r g k 1$ memory phenotype (Fig. $5 C$ ), which suggests the importance of the GTPase domain for memory.

In rescue experiments using the deletion constructs, we aimed to determine whether Rgk1 domains have specific roles in ASM and ARM. The full-length Rgk1, but not the $\Delta \mathrm{N}$ construct, rescued the $\Delta r g k 1$ memory defect after the cold shock application (Fig. 5D), which suggests that the full-length Rgk1 is required to express both ASM and ARM, whereas Rgk $1 \Delta \mathrm{N}$ is sufficient to express ASM but not ARM. It is intriguing that the rescue with the $\operatorname{Rgk} 1 \Delta \mathrm{N}$ construct apparently restored ITM as well as the full-length construct (Fig. 5B) despite the fact that it failed to support ARM (Fig. 5D). These findings suggest that the Rgk $1 \Delta \mathrm{N}$ overexpression may somehow enhance ASM and compensate for its inability to form ARM. conserved among RGK family proteins and is unique to RGK proteins (Puhl et al., 2014), implicating the importance of this region. We found no obvious differences between Rgk1 and GFPRgk1 in the distribution within the KCs or the localization to

\section{Genetic analysis suggests that $r g k 1$ is required for both ASM} and ARM

The previously described results suggest that $r g k 1$ maintains memory through both ASM and ARM. To further confirm the 
A

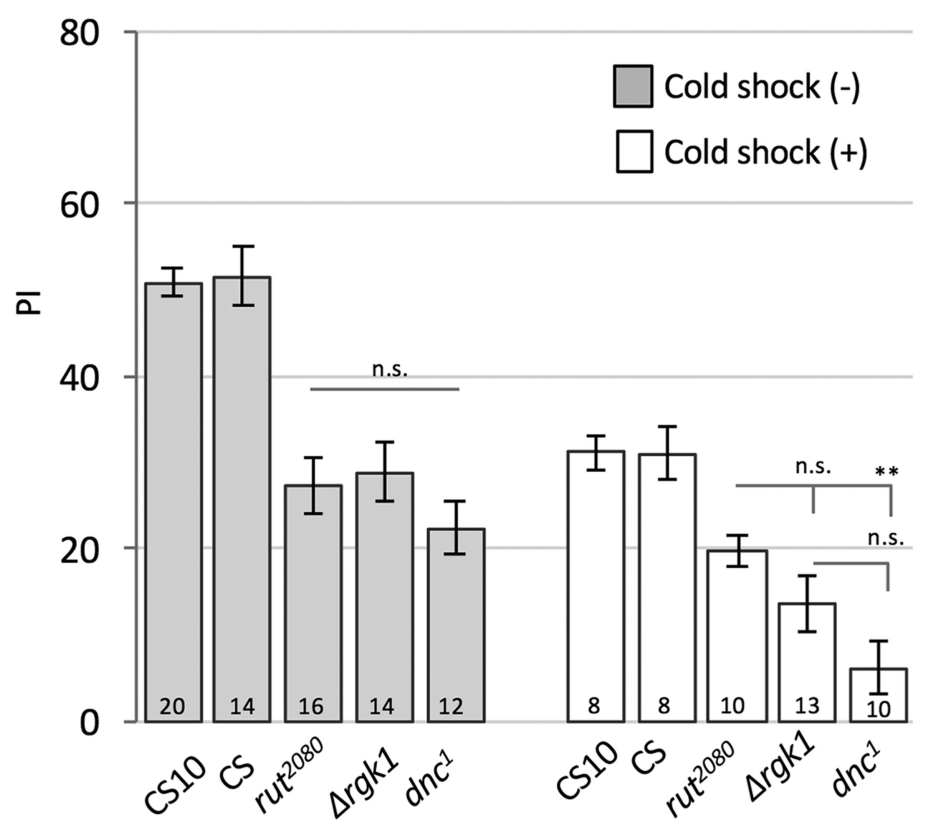

B

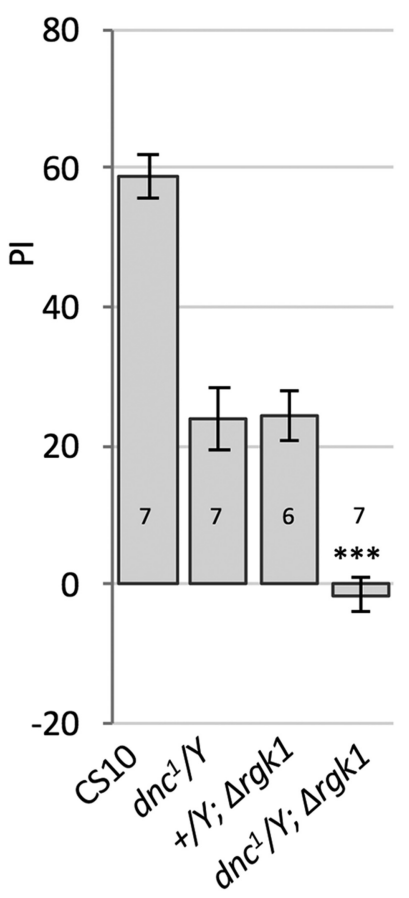

C

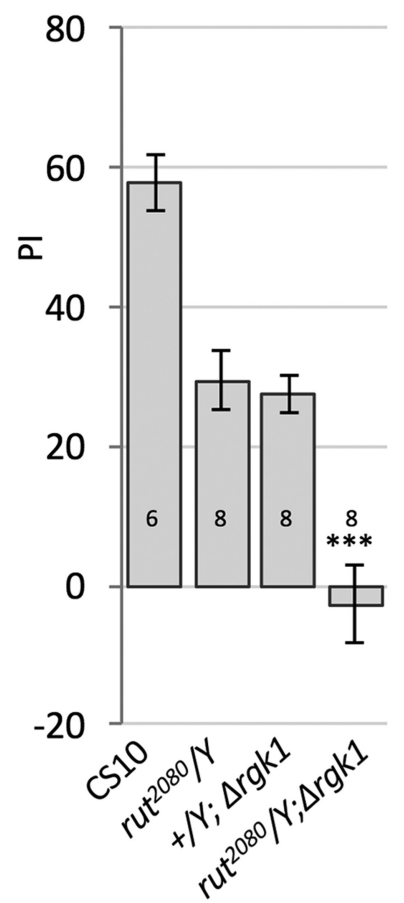

Figure 6. Requirement of $r g k 1$ in ASM and ARM. $A$, Memory scores of rut, $d n c$, and $r g k 1$ mutants with or without cold shock. Although rut exhibited a significant difference in the $3 \mathrm{~h}$ memory scores from $d n c$ after the cold shock, rgk1 did not exhibit a significant difference from rut or $d n$ (without cold shock: $F_{(4,71)}=23.37, p<0.0001$; Fisher's LSD test, rut vs rgk1 $p=0.688$, rut vs $d n c p=$ 0.257 , rgk 1 vs $d n c p=0.142$; with cold shock: $F_{(4,44)}=13.0, p<0.0001$; Fisher's LSD test, rut vs rgk1 $p=0.111$, rut vs $d n c^{* *} p=0.003$, rgk1 vs $\left.d n c p=0.092\right) . B$, C, Removal of rgk 1 in rut or $d n c$ mutants further decreased the $3 \mathrm{~h}$ memory scores of rut or $d n$ c mutants (the double mutant for $d n c$ and rgk1: $F_{(3,23)}=51.31, p<0.0001 ;$ Fisher's LSD test, $d n c$ vs $d n c ;$; $r$ k $1 * * * p<0.0001$, rgk 1 vs $d n c ; r g k 1^{* * *} p<0.0001$; the double mutant for rut and rgk1: $F_{(3,26)}=29.19, p<0.0001$; Fisher's LSD test, rut vs rut;rgk $1^{* * *} p<0.0001$, rgk 1 vs rut;rgk $\left.1^{* * *} p<0.0001\right)$. The data are presented as the mean \pm SEM. $A-C, 3 \mathrm{~h}$ memory.

notion that $r g k 1$ acts for both ASM and ARM, we compared the phenotype of rgkl with known genes specific for ASM or ARM: rutabaga and dunce have been shown to be specifically required for ASM and ARM, respectively (Scheunemann et al., 2012). Three-hour memory was affected to similar degrees in the rgk1, rut, and $d n c$ mutants (Fig. 6A). However, after the cold shock application that eliminates only ASM, a significant difference in the memory scores was observed between rut and $d n c$ as reported previously (Scheunemann et al., 2012), but not between $r g k 1$ and each of the two mutants (Fig. 6A); these findings suggest that rgk1 does not act in the rut or $d n c$ pathway to modulate ASM or ARM specifically. Instead, $r g k 1$ is required for both ASM and ARM. The further removal of the rgkl function from the rut or $d n c$ mutant also confirmed this finding; the removal of $r g k 1$ function deprived the residual memory component that remained in the rut or $d n c$ mutant; that is, the ASM component from $d n c$ and the ARM component from rut (Fig. $6 B, C$ ).

\section{Rgk1 suppressed Rac-dependent memory decay}

A small GTPase, Rac, has been established as the facilitator of forgetting in olfactory memory. Rac acts on ASM and the inhibition of Rac activity leads to memory enhancement (Shuai et al., 2010). In addition, both Rac and RGK proteins regulate cytoskeletal remodeling (Luo, 2000; Etienne-Manneville and Hall, 2002). Therefore, we aimed to assess the potential interplay between Rgk1 and Rac by examining whether rgk1 overexpression suppresses the Rac-dependent memory decay. We determined that the memory defect caused by adult-specific induction of Rac ${ }^{\mathrm{V} 12}$ was suppressed by coexpression of Rgk1 transgenes (Fig. 7A).
The suppressive effect was identified with the Rgk $1 \Delta \mathrm{N}$ construct as well as the full-length construct. In contrast, the $\Delta \mathrm{C}$ construct did not suppress the memory defect, which suggests that the C-terminal region of Rgk1-PB (1120-1380) is necessary to counteract Rac-dependent memory decay. We also investigated whether endogenous $r g k 1$ has a role in the suppression of Racdependent memory decay. When one copy of $\operatorname{rgk} 1$ was removed, the $\mathrm{Rac}^{\mathrm{V} 12}$-dependent memory decay was enhanced (Fig. $7 B, C$ ), which suggests that $r g k 1$ suppresses Rac ${ }^{\mathrm{V} 12}$ activity. These findings indicate that Rgk1 functions, at least in part, through the suppression of Rac-dependent forgetting to maintain memory.

\section{Discussion}

Our genetic analysis demonstrates that $r g k 1$ plays a pivotal role in Drosophila olfactory aversive memory. We propose that the ITM is genetically divided into three components: the rut-, $d n c^{-}$, and rgkl-dependent pathways. The rut and $d n c$ pathway act specifically for ASM and ARM, respectively, whereas $r g k l$ acts for both ASM and ARM, albeit partially. Consistent with this notion, it is noteworthy that the ASM and ARM pathways converge on Rgk1, yet the functional domains may be dissected; the full-length form of Rgk1 is required for ARM, whereas the molecule that lacks the $\mathrm{N}$-terminal domain is capable of generating ASM, which suggests that the protein(s) required for ARM formation may interact with the N-terminal domain of Rgk1.

Our data suggested that Rgk1 acts for both ASM and ARM, whereas the $r g k 1$ deletion mutant, which was shown to be a protein null, exhibited only a partial reduction in ITM; these findings imply that Rgk1 regulates an aspect of each memory component. 
A

$17^{\circ} \mathrm{C}$

$29^{\circ} \mathrm{C}$

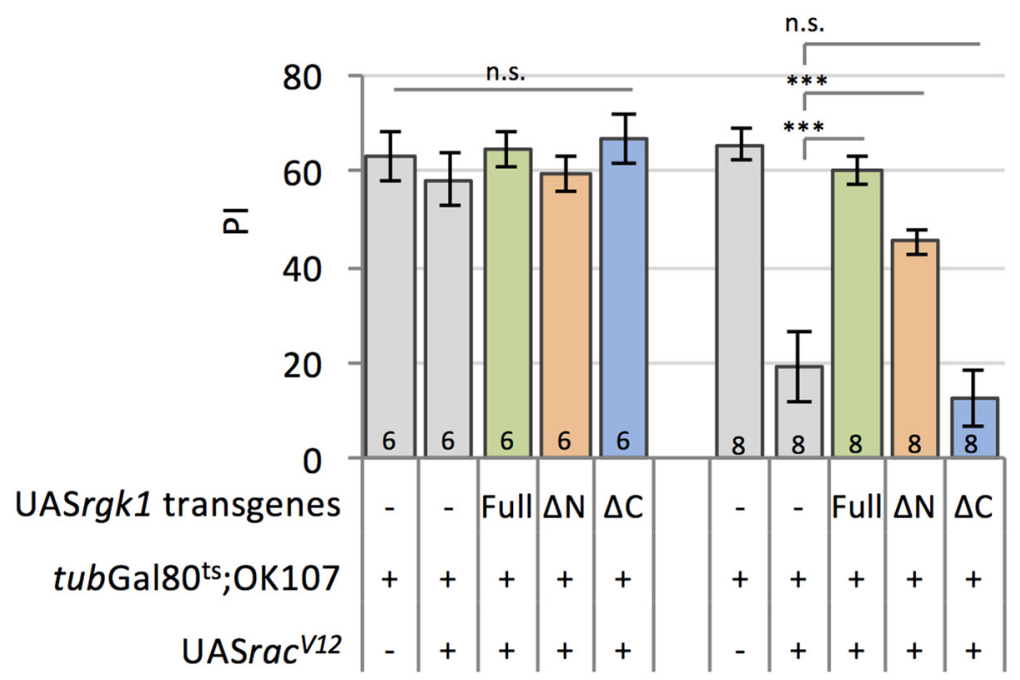

B

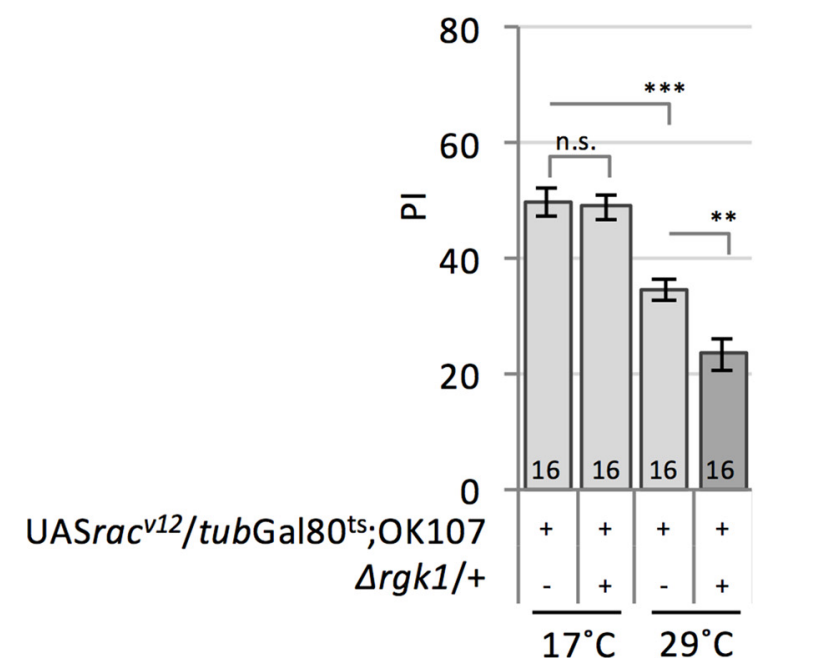

C

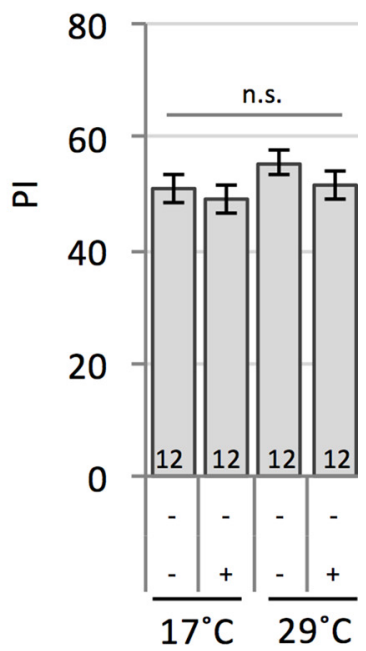

Figure 7. Rgk1 suppressed $\mathrm{Rac}^{\mathrm{V} 12}$-induced memory decay. $\boldsymbol{A}$, When conditionally induced at the adult stage, $\mathrm{Rac}^{\mathrm{V} 12}$ severely disrupted $3 \mathrm{~h}$ memory (Shuai et al., 2010). Coexpression of full-length Rgk1 and Rgk1 $\Delta \mathrm{N}$ canceled the effect of Rac ${ }^{\mathrm{V} 12}$ in contrast to the coexpression of the $\Delta C$ construct $\left(17^{\circ} \mathrm{C}: F_{(4,25)}=0.552, p=0.699,29^{\circ} \mathrm{C}: F_{(4,35)}=24.22, p<0.0001\right.$; Fisher's LSD test,

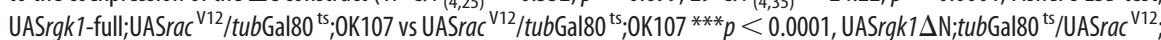

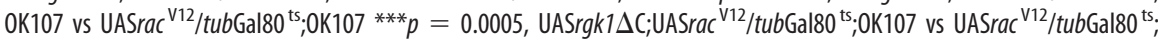
OK107 $p=0.341$ ). GFP-fused rgk1 constructs (Fig. 5A) were used for the experiment. $\boldsymbol{B}$, Removal of one copy of $r g k 1$ enhanced the $3 \mathrm{~h}$ memory decay induced by rac ${ }^{\mathrm{V} 12}\left(F_{(3,60)}=25.99, p<0.0001\right.$; Fisher's LSD test, UASrac ${ }^{\mathrm{V} 12} /$ tubGal $^{\circ}{ }^{\mathrm{ts}} ; 0 \mathrm{~K} 1077^{\circ} 7^{\circ} \mathrm{C}$ vs

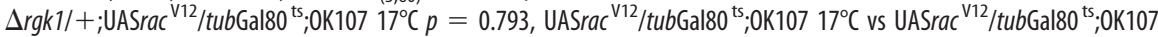

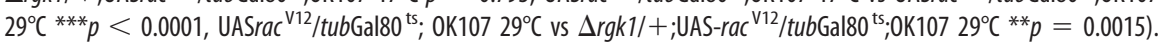
$C$, Temperature shift did not affect the memory performance of $\Delta r g k 1 /+$ animals $\left(F_{(3,44)}=1.18, p=0.328\right)$. Transgene inductions were conducted for $3 \mathrm{~d}(\boldsymbol{A})$ or $2 \mathrm{~d}(\boldsymbol{B})$ at $29^{\circ} C ; \boldsymbol{A}-\boldsymbol{C}, 3 \mathrm{~h}$ memory. The data are presented as the mean \pm SEM.

This idea may be explained by the expression pattern of Rgk1. Rgk1 exhibited exclusive expression and cell-type specificity in the KCs, whereas the memory components have been shown to be regulated by the neuronal network spread outside of the MBs and are encoded by multiple neuronal populations (Berry et al., 2008; Scheunemann et al., 2012; Scholz-Kornehl and Schwarzel, 2016). For example, two parallel pathways exist for ARM (Lee et al., 2011; Wu et al., 2013) and ASM is modulated, not only by MBextrinsic neurons (Waddell et al., 2000; Keene et al., 2006), but also by the ellipsoid body that localizes outside of the MBs (Zhang et al., 2013). dnc-dependent ARM requires antennal lobe local neurons (Scheunemann et al., 2012) and octopamine-dependent ARM requires $\alpha^{\prime} / \beta^{\prime} \mathrm{KCs}$ (Wu et al., 2013), in neither of which was Rgk1 detected. Therefore, Rgk1 may support a specific part of memory components that exists in a subset of KCs.

The specific expression of Rgk1 in KCs suggests its dedicated role in MB function. Rgk1 exhibited cell-type specificity in KCs from anatomical and functional points of view. Rgk1 is strongly expressed in $\alpha / \beta$ and $\gamma \mathrm{KCs}$ and weakly expressed in $\alpha^{\prime} / \beta^{\prime}$ KCs and the expression of the rgkl-sh transgene in $\alpha / \beta$ and $\gamma$ KCs was sufficient to disrupt memory. Several genes required for memory formation have been shown to be expressed preferentially in the KCs and the notable genes include dunce, rutabaga, and DCO (Nighorn et al., 1991; Han et al., 1992; Skoulakis et al., 1993; Davis, 2005; Keene and Waddell, 2007). Although a recent study in $\mathrm{KC}$ dendrites showed that the modulation of neurotransmission into the $\mathrm{KCs}$ affects memory strength (Gai et al., 2016), KC synapses are thought to be the site in which memory is formed and stored (Dubnau et al., 2001; McGuire et al., 2001; Schwaerzel et al., 2003; Hige et al., 2015b; Barnstedt et al., 2016). Our analyses with immunostaining and GFP fusion transgenes indicated that Rgk1 is localized to synaptic sites of the $\mathrm{KC}$ axons, which raises the possibility that Rgk1 may regulate the synaptic plasticity that underlies olfactory memory. Among the RGK family proteins, Rem2 is highly expressed in the CNS and regulates synapse development through interactions with 14-3-3 proteins (Finlin et al., 2000; Ghiretti and Paradis, 2011), which have been shown to be localized to synapses (Zhou et al., 1999) and are required for hippocampal long-term potentiation and associative learning and memory (Qiao et

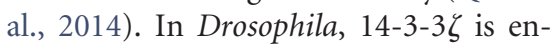
riched in the MBs and is required for olfactory memory (Philip et al., 2001; Messaritou et al., 2009). In addition, the C-terminal region of Drosophila Rgk1 contains serine and threonine residues that exhibit homology to binding sites for 14-3-3 proteins in mammalian RGK proteins (Puhl et al., 2014). Therefore, Rgk1 and $14-3-3 \zeta$ may act together in the synaptic plasticity that underlies olfactory memory.

The roles of RGK family proteins in neuronal functions have been investigated extensively. Our data, when combined with the accumulated data on the function of RGK family proteins, provide novel insights into the mechanism that governs two distinct intermediate-term memories, ASM and ARM. Regarding the reg- 
ulation of ASM, our data showed that Rgk1 suppressed the forgetting that was facilitated by Rac. Rac is a major regulator of cytoskeletal remodeling (Luo, 2000; Etienne-Manneville and Hall, 2002). Similarly, mammalian RGK proteins participate in the regulation of cell shape through the regulation of actin and microtubule remodeling (Piddini et al., 2001; Ward et al., 2002). Rgk1 may affect Rac activity indirectly by sharing an event in which Rac also participates because there have been no reports showing that RGK proteins regulate Rac activity directly; further, we determined that $r g k 1$ transgene expression did not affect the projection defect of $\mathrm{KC}$ axons caused by $\mathrm{Rac}^{\mathrm{V} 12}$ induction during development (data not shown). Therefore, we suggest that Rgk1 signaling and Rac signaling may merge at the level of downstream effectors in the regulation of forgetting. A member of the mammalian RGK1 proteins, Gem, has been shown to regulate Rho GTPase signaling (Correll et al., 2008) through interactions with Ezrin, Gimp, and Rho kinase (Aresta et al., 2002; Ward et al., 2002; Hatzoglou et al., 2007). Rho kinase is a central effector for Rho GTPases (Van Aelst and D’Souza-Schorey, 1997; Hall, 1998; Mackay and Hall, 1998; Kaibuchi et al., 1999) and has been shown to phosphorylate LIM-kinase (Maekawa et al., 1999). In Drosophila, the Rho-kinase ortholog DRok has been shown to interact with LIMkinase (Verdier et al., 2006). Furthermore, Rac regulates actin reorganization through LIM kinase and cofilin (Yang et al., 1998) and the PAK/LIM-kinase/cofilin pathway has been postulated to be critical in the regulation of memory decay by Rac (Shuai et al., 2010). It was shown recently that Scribble scaffolds a signalosome consisting of Rac, Pak3, and Cofilin, which also regulates memory decay (Cervantes-Sandoval et al., 2016). Therefore, Rgk1 may counteract the consequence of Rac activity (i.e., memory decay) through the suppression of the Rho-kinase/LIM-kinase pathway. DRok is a potential candidate for further investigation of the molecular mechanism in which Rgk1 acts to regulate memory decay.

Our data indicated that Rgk1 is required for ARM in addition to ASM. It has been shown that Synapsin and Brp specifically regulate ASM and ARM, respectively (Knapek et al., 2010; Knapek et al., 2011). The functions of Synapsin and Brp may be differentiated in a synapse by regulating distinct modes of neurotransmission (Knapek et al., 2011). The exact mechanism has not been identified for this hypothesis; however, the regulation of voltage-gated calcium channels may be one of the key factors that modulate the neurotransmission (Catterall and Few, 2008; Nakamura et al., 2015). Voltage-gated calcium channels are activated by membrane depolarization and the subsequent $\mathrm{Ca}^{2+}$ increase triggers synaptic vesicle release (Catterall and Few, 2008). The regulation of voltage-gated calcium channels has been shown to be important in memory; a $\beta$-subunit of voltage-dependent $\mathrm{Ca}^{2+}$ channels, $\mathrm{Ca}_{\mathrm{v}} \beta 3$, negatively regulates memory in rodents (Jeon et al., 2008). Importantly, Brp regulates the clustering of $\mathrm{Ca}^{2+}$ channels at the active zone (Kittel et al., 2006). Moreover, it has been demonstrated extensively that mammalian RGK family proteins regulate voltage-gated calcium channels. Kir/Gem and Rem 2 interact with the $\mathrm{Ca}^{2+}$ channel $\beta$-subunit and regulate $\mathrm{Ca}^{2+}$ channel activity (Béguin et al., 2001; Finlin et al., 2003; Yang and Colecraft, 2013). In addition, the ability to regulate $\mathrm{Ca}^{2+}$ channels has been shown to be conserved in Drosophila Rgk1 (Puhl et al., 2014). Therefore, both Brp and Rgk1 may regulate ARM through the regulation of calcium channels, the former through the regulation of their assembly and the latter through the direct regulation of their activity. Our finding that Rgk1 localized to the synaptic site and colocalized with Brp lends plausibility to the scenario that Rgk1 regulates voltage-gated calcium channels at the active zone.
Several memory genes identified in Drosophila, including rutabaga, $P K A-R$, and $C R E B$, have homologous genes that have been shown to regulate behavioral plasticity in other species ( $\mathrm{Wu}$ et al., 1995; Abel et al., 1997; Davis, 2005; Kida and Serita, 2014). The identification of Drosophila $r g k 1$ as a novel memory gene raises the possibility for another conserved mechanism that governs memory. There is limited research regarding the role of RGK proteins at the behavioral level in other species; however, the extensively documented functions of RGK proteins with respect to the regulation of neuronal functions, combined with our data presented here regarding Drosophila Rgk1, raise the possibility of an evolutionally conserved function for RGK family proteins in memory.

Note Added in Proof: During the proof processing, a close scrutiny of the entire data revealed several errors in posting during the statistical analysis (Fig. 2A, Fig. $4 C-F$, Fig. $6 A$ ), as well as in a brain image processing (Fig. $3 D$ ). These errors have been corrected appropriately. None of them changed any conclusions.

\section{References}

Abe T, Yamazaki D, Murakami S, Hiroi M, Nitta Y, Maeyama Y, Tabata T (2014) The NAV2 homolog Sickie regulates F-actin-mediated axonal growth in Drosophila mushroom body neurons via the non-canonical Rac-Cofilin pathway. Development 141:4716-4728. CrossRef Medline

Abel T, Nguyen PV, Barad M, Deuel TA, Kandel ER, Bourtchouladze R (1997) Genetic demonstration of a role for PKA in the late phase of LTP and in hippocampus-based long-term memory. Cell 88:615-626. CrossRef Medline

Aresta S, de Tand-Heim MF, Béranger F, de Gunzburg J (2002) A novel Rho GTPase-activating-protein interacts with Gem, a member of the Ras superfamily of GTPases. Biochem J 367:57-65. CrossRef Medline

Aso Y, Hattori D, Yu Y, Johnston RM, Iyer NA, Ngo TT, Dionne H, Abbott LF, Axel R, Tanimoto H, Rubin GM (2014) The neuronal architecture of the mushroom body provides a logic for associative learning. Elife 3:e04577. CrossRef Medline

Barnstedt O, Owald D, Felsenberg J, Brain R, Moszynski JP, Talbot CB, Perrat PN, Waddell S (2016) Memory-relevant mushroom body output synapses are cholinergic. Neuron 89:1237-1247. CrossRef Medline

Béguin P, Nagashima K, Gonoi T, Shibasaki T, Takahashi K, Kashima Y, Ozaki N, Geering K, Iwanaga T, Seino S (2001) Regulation of Ca2+ channel expression at the cell surface by the small G-protein kir/Gem. Nature 411:701-706. CrossRef Medline

Bellen HJ, Levis RW, Liao G, He Y, Carlson JW, Tsang G, Evans-Holm M, Hiesinger PR, Schulze KL, Rubin GM, Hoskins RA, Spradling AC (2004) The BDGP gene disruption project: single transposon insertions associated with $40 \%$ of Drosophila genes. Genetics 167:761-781. CrossRef Medline

Berry JA, Cervantes-Sandoval I, Nicholas EP, Davis RL (2012) Dopamine is required for learning and forgetting in Drosophila. Neuron 74:530-542. CrossRef Medline

Berry J, Krause WC, Davis RL (2008) Olfactory memory traces in Drosophila. Prog Brain Res 169:293-304. CrossRef Medline

Bouzaiane E, Trannoy S, Scheunemann L, Plaçais PY, Preat T (2015) Two independent mushroom body output circuits retrieve the six discrete components of Drosophila aversive memory. Cell Rep 11:1280-1292. CrossRef Medline

Brand AH, Perrimon N (1993) Targeted gene expression as a means of altering cell fates and generating dominant phenotypes. Development 118:401-415. Medline

Busto GU, Cervantes-Sandoval I, Davis RL (2010) Olfactory learning in Drosophila. Physiology (Bethesda) 25:338-346. CrossRef Medline

Catterall WA, Few AP (2008) Calcium channel regulation and presynaptic plasticity. Neuron 59:882-901. CrossRef Medline

Cervantes-Sandoval I, Chakraborty M, MacMullen C, Davis RL (2016) Scribble scaffolds a signalosome for active forgetting. Neuron 90:12301242. CrossRef Medline

Connolly JB, Roberts IJ, Armstrong JD, Kaiser K, Forte M, Tully T, O’Kane CJ (1996) Associative learning disrupted by impaired Gs signaling in Drosophila mushroom bodies. Science 274:2104-2107. CrossRef Medline

Correll RN, Pang C, Niedowicz DM, Finlin BS, Andres DA (2008) The RGK family of GTP-binding proteins: regulators of voltage-dependent calcium 
channels and cytoskeleton remodeling. Cell Signal 20:292-300. CrossRef Medline

Davis RL (1993) Mushroom bodies and Drosophila learning. Neuron 11:114. CrossRef Medline

Davis RL (1996) Physiology and biochemistry of Drosophila learning mutants. Physiol Rev 76:299-317. Medline

Davis RL (2005) Olfactory memory formation in Drosophila: from molecular to systems neuroscience. Annu Rev Neurosci 28:275-302. CrossRef Medline

Davis RL (2011) Traces of Drosophila memory. Neuron 70:8-19. CrossRef Medline

Dubnau J, Grady L, Kitamoto T, Tully T (2001) Disruption of neurotransmission in Drosophila mushroom body blocks retrieval but not acquisition of memory. Nature 411:476-480. CrossRef Medline

Dubnau J, Chiang AS, Tully T (2003) Neural substrates of memory: from synapse to system. J Neurobiol 54:238-253. CrossRef Medline

Dudai Y (1985) Some properties of adenylate cyclase which might be important for memory formation. FEBS Lett 191:165-170. CrossRef Medline

Dudai Y (1988) Neurogenetic dissection of learning and short-term memory in Drosophila. Annu Rev Neurosci 11:537-563. CrossRef Medline

Etienne-Manneville S, Hall A (2002) Rho GTPases in cell biology. Nature 420:629-635. CrossRef Medline

Farnsworth CL, Feig LA (1991) Dominant inhibitory mutations in the $\mathrm{Mg}(2+)$-binding site of RasH prevent its activation by GTP. Mol Cell Biol 11:4822-4829. CrossRef Medline

Feig LA, Cooper GM (1988) Inhibition of NIH 3 T3 cell proliferation by a mutant ras protein with preferential affinity for GDP. Mol Cell Biol 8:3235-3243. CrossRef Medline

Finlin BS, Shao H, Kadono-Okuda K, Guo N, Andres DA (2000) Rem2, a new member of the Rem/Rad/Gem/Kir family of Ras-related GTPases. Biochem J 347:223-231. Medline

Finlin BS, Crump SM, Satin J, Andres DA (2003) Regulation of voltagegated calcium channel activity by the Rem and Rad GTPases. Proc Natl Acad Sci U S A 100:14469-14474. CrossRef Medline

Folkers E, Drain P, Quinn WG (1993) Radish, a Drosophila mutant deficient in consolidated memory. Proc Natl Acad Sci U S A 90:8123-8127. CrossRef Medline

Gai Y, Liu Z, Cervantes-Sandoval I, Davis RL (2016) Drosophila SLC22A transporter is a memory suppressor gene that influences cholinergic neurotransmission to the mushroom bodies. Neuron 90:581-595. CrossRef Medline

Ghiretti AE, Paradis S (2011) The GTPase Rem2 regulates synapse development and dendritic morphology. Dev Neurobiol 71:374-389. CrossRef Medline

Ghiretti AE, Paradis S (2014) Molecular mechanisms of activity-dependent changes in dendritic morphology: role of RGK proteins. Trends Neurosci 37:399-407. CrossRef Medline

Ghiretti AE, Moore AR, Brenner RG, Chen LF, West AE, Lau NC, Van Hooser SD, Paradis S (2014) Rem2 is an activity-dependent negative regulator of dendritic complexity in vivo. J Neurosci 34:392-407. CrossRef Medline

Grams R, Korge G (1998) The mub gene encodes a protein containing three $\mathrm{KH}$ domains and is expressed in the mushroom bodies of Drosophila melanogaster. Gene 215:191-201. CrossRef Medline

Guven-Ozkan T, Davis RL (2014) Functional neuroanatomy of Drosophila olfactory memory formation. Learn Mem 21:519-526. CrossRef Medline

Hall A (1998) Rho GTPases and the actin cytoskeleton. Science 279:509514. CrossRef Medline

Han PL, Levin LR, Reed RR, Davis RL (1992) Preferential expression of the Drosophila rutabaga gene in mushroom bodies, neural centers for learning in insects. Neuron 9:619-627. CrossRef Medline

Hanson DA, Ziegler SF (2004) Fusion of green fluorescent protein to the C-terminus of granulysin alters its intracellular localization in comparison to the native molecule. J Negat Results Biomed 3:2. CrossRef Medline

Hatzoglou A, Ader I, Splingard A, Flanders J, Saade E, Leroy I, Traver S, Aresta S, de Gunzburg J (2007) Gem associates with Ezrin and acts via the Rho-GAP protein Gmip to down-regulate the Rho pathway. Mol Biol Cell 18:1242-1252. CrossRef Medline

Hayashi S, Ito K, Sado Y, Taniguchi M, Akimoto A, Takeuchi H, Aigaki T, Matsuzaki F, Nakagoshi H, Tanimura T, Ueda R, Uemura T, Yoshihara M, Goto S (2002) GETDB, a database compiling expression patterns and molecular locations of a collection of Gal4 enhancer traps. Genesis 34:58-61. CrossRef Medline
Heisenberg M (2003) Mushroom body memoir: from maps to models. Nat Rev Neurosci 4:266-275. CrossRef Medline

Hige T, Aso Y, Rubin GM, Turner GC (2015a) Plasticity-driven individualization of olfactory coding in mushroom body output neurons. Nature 526:258-262. CrossRef Medline

Hige T, Aso Y, Modi MN, Rubin GM, Turner GC (2015b) Heterosynaptic plasticity underlies aversive olfactory learning in Drosophila. Neuron 88: 985-998. CrossRef Medline

Isabel G, Pascual A, Preat T (2004) Exclusive consolidated memory phases in Drosophila. Science 304:1024-1027. CrossRef Medline

Ito K, Awano W, Suzuki K, Hiromi Y, Yamamoto D (1997) The Drosophila mushroom body is a quadruple structure of clonal units each of which contains a virtually identical set of neurones and glial cells. Development 124:761-771. Medline

Jeon D, Song I, Guido W, Kim K, Kim E, Oh U, Shin HS (2008) Ablation of $\mathrm{Ca} 2+$ channel beta3 subunit leads to enhanced N-methyl-D-aspartate receptor-dependent long term potentiation and improved long term memory. J Biol Chem 283:12093-12101. CrossRef Medline

Kaibuchi K, Kuroda S, Amano M (1999) Regulation of the cytoskeleton and cell adhesion by the Rho family GTPases in mammalian cells. Annu Rev Biochem 68:459-486. CrossRef Medline

Keene AC, Waddell S (2007) Drosophila olfactory memory: single genes to complex neural circuits. Nat Rev Neurosci 8:341-354. Medline

Keene AC, Krashes MJ, Leung B, Bernard JA, Waddell S (2006) Drosophila dorsal paired medial neurons provide a general mechanism for memory consolidation. Curr Biol 16:1524-1530. CrossRef Medline

Kida S, Serita T (2014) Functional roles of CREB as a positive regulator in the formation and enhancement of memory. Brain Res Bull 105:17-24. CrossRef Medline

Kittel RJ, Wichmann C, Rasse TM, Fouquet W, Schmidt M, Schmid A, Wagh DA, Pawlu C, Kellner RR, Willig KI, Hell SW, Buchner E, Heckmann M, Sigrist SJ (2006) Bruchpilot promotes active zone assembly, Ca2 + channel clustering, and vesicle release. Science 312:1051-1054. CrossRef Medline

Knapek S, Gerber B, Tanimoto H (2010) Synapsin is selectively required for anesthesia-sensitive memory. Learn Mem 17:76-79. CrossRef Medline

Knapek S, Sigrist S, Tanimoto H (2011) Bruchpilot, a synaptic active zone protein for anesthesia-resistant memory. J Neurosci 31:3453-3458. CrossRef Medline

Kurimoto K, Yabuta Y, Ohinata Y, Saitou M (2007) Global single-cell cDNA amplification to provide a template for representative high-density oligonucleotide microarray analysis. Nat Protoc 2:739-752. CrossRef Medline

Lee PT, Lin HW, Chang YH, Fu TF, Dubnau J, Hirsh J, Lee T, Chiang AS (2011) Serotonin-mushroom body circuit modulating the formation of anesthesia-resistant memory in Drosophila. Proc Natl Acad Sci U S A 108: 13794-13799. CrossRef Medline

Leone A, Mitsiades N, Ward Y, Spinelli B, Poulaki V, Tsokos M, Kelly K (2001) The Gem GTP-binding protein promotes morphological differentiation in neuroblastoma. Oncogene 20:3217-3225. CrossRef Medline

Lin DM, Fetter RD, Kopczynski C, Grenningloh G, Goodman CS (1994) Genetic analysis of Fasciclin II in Drosophila: defasciculation, refasciculation, and altered fasciculation. Neuron 13:1055-1069. CrossRef Medline

Luo L (2000) Rho GTPases in neuronal morphogenesis. Nat Rev Neurosci 1:173-180. CrossRef Medline

Luo L, Liao YJ, Jan LY, Jan YN (1994) Distinct morphogenetic functions of similar small GTPases: Drosophila Drac1 is involved in axonal outgrowth and myoblast fusion. Genes Dev 8:1787-1802. CrossRef Medline

Mackay DJ, Hall A (1998) Rho GTPases. J Biol Chem 273:20685-20688. CrossRef Medline

Maekawa M, Ishizaki T, Boku S, Watanabe N, Fujita A, Iwamatsu A, Obinata T, Ohashi K, Mizuno K, Narumiya S (1999) Signaling from Rho to the actin cytoskeleton through protein kinases ROCK and LIM-kinase. Science 285:895-898. CrossRef Medline

Margulies C, Tully T, Dubnau J (2005) Deconstructing memory in Drosophila. Curr Biol 15:R700-R713. CrossRef Medline

McGuire SE, Le PT, Davis RL (2001) The role of Drosophila mushroom body signaling in olfactory memory. Science 293:1330-1333. CrossRef Medline

McGuire SE, Mao Z, Davis RL (2004) Spatiotemporal gene expression targeting with the TARGET and gene-switch systems in Drosophila. Sci STKE 2004:pl6. Medline

McGuire SE, Deshazer M, Davis RL (2005) Thirty years of olfactory learning and memory research in Drosophila melanogaster. Prog Neurobiol 76: 328-347. CrossRef Medline 
Messaritou G, Leptourgidou F, Franco M, Skoulakis EM (2009) A third functional isoform enriched in mushroom body neurons is encoded by the Drosophila 14-3-3zeta gene. FEBS Lett 583:2934-2938. CrossRef Medline

Moore AR, Ghiretti AE, Paradis S (2013) A loss-of-function analysis reveals that endogenous Rem2 promotes functional glutamatergic synapse formation and restricts dendritic complexity. PLoS One 8:e74751. CrossRef Medline

Murakami S, Dan C, Zagaeski B, Maeyama Y, Kunes S, Tabata T (2010) Optimizing Drosophila olfactory learning with a semi-automated training device. J Neurosci Methods 188:195-204. CrossRef Medline

Nakamura Y, Harada H, Kamasawa N, Matsui K, Rothman JS, Shigemoto R, Silver RA, DiGregorio DA, Takahashi T (2015) Nanoscale distribution of presynaptic $\mathrm{Ca}(2+)$ channels and its impact on vesicular release during development. Neuron 85:145-158. CrossRef Medline

Ni JQ, Zhou R, Czech B, Liu LP, Holderbaum L, Yang-Zhou D, Shim HS, Tao R, Handler D, Karpowicz P, Binari R, Booker M, Brennecke J, Perkins LA, Hannon GJ, Perrimon N (2011) A genome-scale shRNA resource for transgenic RNAi in Drosophila. Nat Methods 8:405-407. CrossRef Medline

Nighorn A, Healy MJ, Davis RL (1991) The cyclic AMP phosphodiesterase encoded by the Drosophila dunce gene is concentrated in the mushroom body neuropil. Neuron 6:455-467. CrossRef Medline

O’Dell KM, Armstrong JD, Yang MY, Kaiser K (1995) Functional dissection of the Drosophila mushroom bodies by selective feminization of genetically defined subcompartments. Neuron 15:55-61. CrossRef Medline

Owald D, Waddell S (2015) Olfactory learning skews mushroom body output pathways to steer behavioral choice in Drosophila. Curr Opin Neurobiol 35:178-184. CrossRef Medline

Pan JY, Fieles WE, White AM, Egerton MM, Silberstein DS (2000) Ges, A human GTPase of the Rad/Gem/Kir family, promotes endothelial cell sprouting and cytoskeleton reorganization. J Cell Biol 149:1107-1116. CrossRef Medline

Parks AL, et al. (2004) Systematic generation of high-resolution deletion coverage of the Drosophila melanogaster genome. Nat Genet 36:288-292. CrossRef Medline

Philip N, Acevedo SF, Skoulakis EM (2001) Conditional rescue of olfactory learning and memory defects in mutants of the 14-3-3zeta gene Leonardo. J Neurosci 21:8417-8425. Medline

Piddini E, Schmid JA, de Martin R, Dotti CG (2001) The Ras-like GTPase Gem is involved in cell shape remodelling and interacts with the novel kinesin-like protein KIF9. EMBO J 20:4076-4087. CrossRef Medline

Plaçais PY, Trannoy S, Isabel G, Aso Y, Siwanowicz I, Belliart-Guérin G, Vernier P, Birman S, Tanimoto H, Preat T (2012) Slow oscillations in two pairs of dopaminergic neurons gate long-term memory formation in Drosophila. Nat Neurosci 15:592-599. CrossRef Medline

Puhl HL 3rd, Lu VB, Won YJ, Sasson Y, Hirsch JA, Ono F, Ikeda SR (2014) Ancient origins of RGK protein function: modulation of voltage-gated calcium channels preceded the protostome and deuterostome split. PLoS One 9:e100694. CrossRef Medline

Qiao H, Foote M, Graham K, Wu Y, Zhou Y (2014) 14-3-3 proteins are required for hippocampal long-term potentiation and associative learning and memory. J Neurosci 34:4801-4808. CrossRef Medline

Quinn WG, Dudai Y (1976) Memory phases in Drosophila. Nature 262: 576-577. CrossRef Medline

Quinn WG, Harris WA, Benzer S (1974) Conditioned behavior in Drosophila melanogaster. Proc Natl Acad Sci U S A 71:708-712. CrossRef Medline

Robertson HM, Preston CR, Phillis RW, Johnson-Schlitz DM, Benz WK, Engels WR (1988) A stable genomic source of P element transposase in Drosophila melanogaster. Genetics 118:461-470. Medline

Robinson IM, Ranjan R, Schwarz TL (2002) Synaptotagmins I and IV promote transmitter release independently of $\mathrm{Ca}(2+)$ binding in the C(2)A domain. Nature 418:336-340. CrossRef Medline

Scheunemann L, Jost E, Richlitzki A, Day JP, Sebastian S, Thum AS, Efetova M, Davies SA, Schwärzel M (2012) Consolidated and labile odor memory are separately encoded within the Drosophila brain. J Neurosci 32: 17163-17171. CrossRef Medline

Scholz-Kornehl S, Schwärzel M (2016) Circuit analysis of a Drosophila dopamine type 2 receptor that supports anesthesia-resistant memory. J Neurosci 36:7936-7945. CrossRef Medline

Schwaerzel M, Monastirioti M, Scholz H, Friggi-Grelin F, Birman S, Heisenberg M (2003) Dopamine and octopamine differentiate between aversive and appetitive olfactory memories in Drosophila. J Neurosci 23: 10495-10502. Medline
Schwaerzel M, Jaeckel A, Mueller U (2007) Signaling at A-kinase anchoring proteins organizes anesthesia-sensitive memory in Drosophila. J Neurosci 27:1229-1233. CrossRef Medline

Shuai Y, Lu B, Hu Y, Wang L, Sun K, Zhong Y (2010) Forgetting is regulated through Rac activity in Drosophila. Cell 140:579-589. CrossRef Medline

Skoulakis EM, Kalderon D, Davis RL (1993) Preferential expression in mushroom bodies of the catalytic subunit of protein kinase A and its role in learning and memory. Neuron 11:197-208. CrossRef Medline

Steele FR, Washburn T, Rieger R, O’Tousa JE (1992) Drosophila retinal degeneration $\mathrm{C}(\mathrm{rdgC})$ encodes a novel serine/threonine protein phosphatase. Cell 69:669-676. CrossRef Medline

Tanaka NK, Tanimoto H, Ito K (2008) Neuronal assemblies of the Drosophila mushroom body. J Comp Neurol 508:711-755. CrossRef Medline

Tang F, Barbacioru C, Wang Y, Nordman E, Lee C, Xu N, Wang X, Bodeau J, Tuch BB, Siddiqui A, Lao K, Surani MA (2009) mRNA-Seq whole-transcriptome analysis of a single cell. Nat Methods 6:377-382. CrossRef Medline

Trannoy S, Redt-Clouet C, Dura JM, Preat T (2011) Parallel processing of appetitive short- and long-term memories in Drosophila. Curr Biol 21: 1647-1653. CrossRef Medline

Tully T, Quinn WG (1985) Classical conditioning and retention in normal and mutant Drosophila melanogaster. J Comp Physiol A 157:263-277. CrossRef Medline

Tully T, Preat T, Boynton SC, Del Vecchio M (1994) Genetic dissection of consolidated memory in Drosophila. Cell 79:35-47. CrossRef Medline

Van Aelst L, D'Souza-Schorey C (1997) Rho GTPases and signaling networks. Genes Dev 11:2295-2322. CrossRef Medline

Verdier V, Guang-Chao-Chen, Settleman J (2006) Rho-kinase regulates tissue morphogenesis via non-muscle myosin and LIM-kinase during Drosophila development. BMC Dev Biol 6:38. CrossRef Medline

Vert JP, Foveau N, Lajaunie C, Vandenbrouck Y (2006) An accurate and interpretable model for siRNA efficacy prediction. BMC Bioinformatics 7:520. CrossRef Medline

Waddell S, Quinn WG (2001) What can we teach Drosophila? What can they teach us? Trends Genet 17:719-726. CrossRef Medline

Waddell S, Armstrong JD, Kitamoto T, Kaiser K, Quinn WG (2000) The amnesiac gene product is expressed in two neurons in the Drosophila brain that are critical for memory. Cell 103:805-813. CrossRef Medline

Wagh DA, Rasse TM, Asan E, Hofbauer A, Schwenkert I, Dürrbeck H, Buchner S, Dabauvalle MC, Schmidt M, Qin G, Wichmann C, Kittel R, Sigrist SJ, Buchner E (2006) Bruchpilot, a protein with homology to ELKS/ CAST, is required for structural integrity and function of synaptic active zones in Drosophila. Neuron 49:833-844. CrossRef Medline

Wang Y, Navin NE (2015) Advances and applications of single-cell sequencing technologies. Mol Cell 58:598-609. CrossRef Medline

Wang Z, Gerstein M, Snyder M (2009) RNA-Seq: a revolutionary tool for transcriptomics. Nat Rev Genet 10:57-63. CrossRef Medline

Ward Y, Yap SF, Ravichandran V, Matsumura F, Ito M, Spinelli B, Kelly K (2002) The GTP binding proteins Gem and Rad are negative regulators of the Rho-Rho kinase pathway. J Cell Biol 157:291-302. CrossRef Medline

Wu CL, Shih MF, Lee PT, Chiang AS (2013) An octopamine-mushroom body circuit modulates the formation of anesthesia-resistant memory in Drosophila. Curr Biol 23:2346-2354. CrossRef Medline

Wu ZL, Thomas SA, Villacres EC, Xia Z, Simmons ML, Chavkin C, Palmiter $\mathrm{RD}$, Storm DR (1995) Altered behavior and long-term potentiation in type I adenylyl cyclase mutant mice. Proc Natl Acad Sci U S A 92:220224. CrossRef Medline

Yang N, Higuchi O, Ohashi K, Nagata K, Wada A, Kangawa K, Nishida E, Mizuno K (1998) Cofilin phosphorylation by LIM-kinase 1 and its role in Racmediated actin reorganization. Nature 393:809-812. CrossRef Medline

Yang T, Colecraft HM (2013) Regulation of voltage-dependent calcium channels by RGK proteins. Biochim Biophys Acta 1828:1644-1654. CrossRef Medline

Zars T, Fischer M, Schulz R, Heisenberg M (2000) Localization of a shortterm memory in Drosophila. Science 288:672-675. CrossRef Medline

Zhang Z, Li X, Guo J, Li Y, Guo A (2013) Two clusters of GABAergic ellipsoid body neurons modulate olfactory labile memory in Drosophila. J Neurosci 33:5175-5181. CrossRef Medline

Zhou Y, Schopperle WM, Murrey H, Jaramillo A, Dagan D, Griffith LC, Levitan IB (1999) A dynamically regulated 14-3-3, Slob, and Slowpoke potassium channel complex in Drosophila presynaptic nerve terminals. Neuron 22:809-818. CrossRef Medline 